\title{
Türk Daması Oyun Kültürü ve Türkiye'deki Dama Oynanan Kahvehanelerin İç Mekânlarının İncelemesi
}

\author{
Bülent AYBERK ${ }^{1 *}$
}

\section{öz}

Dama oyununun özellikle İslam coğrafyasında kabul görerek ve yaygınlıkla oynandığı görülmektedir. Haçlı seferleri ile batıya taşınan oyunun zaman içinde pek çok türü ortaya çıkmıştır. Anadolu'da oynanan dama, Türk daması olarak adlandırılmaktadır. Türk kültürünün önemli bir öğesi olan bu türr, özellikle Osmanlı döneminde altın devirlerini yaşamıştır. Osmanlı padişahlarının da ilgi gösterdiği bu oyun için sarayda damacıbaşıların işlendirildiği bilinmektedir. Böylece günümüze kadar etkisini sürdürecek olan oyun geleneğinin bu dönemden itibaren biçimlenmeye başladığı görülmektedir. Sonrasında uzun yıllara yayılan bir süreç içinde; ilginin giderek kaybolması sonucu olarak oyuncu kitlesi azalmıştır. Ancak bu kültür kaybolmamış; Türk kültürünün önemli bir bileşeni olan kahvehanelerin, kültür aktarımındaki güçlü etkisiyle kuşaktan kuşağa aktarılarak günümüze kadar ulaşmıştır. Bugün, Türkiye'nin farklı yerlerine dağılmış ve dama oyununun yaşaması için çaba gösteren bir oyuncu kitlesi bulunmaktadır. Bu yazının oluşum sürecinde Türkiye'nin farklı bölgelerindeki dama oynanan kahvehaneler ziyaret edilmiş, dama oyun kültürüne ilişkin veriler toplanmaya çalışılmış ve kahvehane iç mekanları ve bu mekanlardaki oyun mobilyaları ve çevresel birimleri incelenerek mekan tipolojileri belirlenmeye çalışılmıştır.

Anahtar Kelimeler: Dama oyunu, Dama Kahvehaneleri, Türk Daması, Kahvehaneler, İ̧ Mekan.

\section{Turkish Draught Game Culture and Survey On Draught Cafes in Turkey}

\begin{abstract}
It is observed draught is widely played in Muslim counties with mutual great acceptence. The game has been risen to different types through the ages which had been brought to the west by the crusaders. The type specifically played in Anatolia region called Turkish draught. This type of draught is a significant element of Turkish culture which had its golden ages in Ottoman Empire. It is this age that a great tradition was created and continued to present times. Ottoman sultans showed so great interest, that the chief draught players were employed. After having lost public interest, it began losing players as well. But the culture has not been lost completely. Until now it has been survived from one generation to the next by the cafehouses which has strong feature to preserve culture. Today there is a a society on which make an great effort to struggle, scattered through the different parts of Turkiye. For this dissertation, many cafes visited to obtain knowledge on draught and to survey the typologies of the interiors and furnitures with peripherial units.
\end{abstract}

Keywords: Draught Game, Draught Cafehouses, Turkish Draught, Cafehouses, Interiors.

\footnotetext{
${ }^{1}$ Kocaeli Üniversitesi, Mimarlık ve Tasarım Fakültesi, İç Mimarlık Bölümü, bulent.ayberk@kocaeli.edu.tr *ilgili yazar / Corresponding author: Bülent AYBERK, bulent.ayberk@kocaeli.edu.tr Gönderim Tarihi: 28.11.2016

Kabul Tarihi: 13.12.2016
} 


\section{DAMA OYUNU}

Murray, geleneksel masa oyunları için beş sınıf belirlemiştir. Bunlar; hizalama ve konumlandırma oyunları, savaş oyunları, av oyunları, yarış oyunları ve mangala oyunları başlıklarının altında toplanmaktadır. Murray'ın bu sınıflandırmasının mantığı, oyunların insanoğlunun erken dönemi etkinliklerinin temsili olduğu düşüncesine dayanmaktadır. Bu sınıflandırma başlıkları incelendiğinde, rakibin tüm taşlarının ele geçirilmesi veya etkisiz kılınmasının amaçlandığı savaş oyunlarının dama oyununu da kapsamakta olduğu görülmektedir (Cengiz, 2008, 21).

Parlett ise, oyunların altyapılarında yatan soyut prensipleri değerlendirerek bir sınıflandırma yapma yoluna gitmiştir. Bu sınıflar yarış, espas, kovalama, çıkarma ve tematik oyunlar başlıkları altındadır (Cengiz, 2008, 24).

Bu sınıflandırma içinde dama, çıkarma oyunları içinde değerlendirilmektedir. Ancak yazar, bu sınıflandırma içinde ayrıntılı bir sınıflandırma daha yapmıştır. Bu başlıklar belirlenirken temel aldığı ilke, oyun taşlarının oyun süreci içinde işlevsel açıdan birbirinden farklılaşabilme olanaklarıdır. Doğrusal (ve farksız), farksız, yarı farklılaştırılmış, farklılaştırılmış olarak tanımlanan bu işlevsellik durumlarının arasında yarı farklılaştıııımış olma durumu, dama oyunundaki yoz taşın sekizinci kareye çıkması ile dama taşı işlevini kazanması özelliğini tanımlamaktadır (Cengiz, 2008, 24).

Dama, kültürlerdeki farklı oyun anlayışları sonucu kendi içinde de türlere ayrılmıştır. Kaynaklarda özellikle yer verilen dünyadaki dama türleri olarak aşağıdakiler öncelikli olarak belirtilmektedir.

Polonya daması: Avrupa daması olarak da adlandırılmaktadır. 100 karelik bir oyun yüzeyinde 20'şer taşla oynanır. Taşlar çapraz olarak ileriye doğru hareket eder ancak taş alırken hem ileri hem geri gidebilir.

Alman daması: Polonya damasının bir türüdür. 64 karelik bir oyun yüzeyinde 12'şer taşla oynanmaktadır.

İspanyol daması: İngiltere ve Amerika'da oynanan damaya benzemektedir. Bu damada taşlar ileri gittiği gibi geriye doğru da gidebilmektedir. Damaya çıkan taş aynı yönde olmak üzere çaprazındaki bütün boş karelerden geçebilir. Yolu üzerindeki taşları alabilir ve taş almak için yön değiştirebilir.Halma: Yunanca bir fiil olarak "atla" anlamına gelmektedir. 1880 dolaylarında ortaya çıkmıştır. Oyuncular 256 karelik bir oyun yüzeyinde oynamaktadır. İki kişi 19'ar taşla, dört kişi ise 13'er taşla oynar. Dört kişilik oyunda iki kişi ortak olabilir. Oyunu üç kişi de oynayabilmektedir ancak karşısında rakip bulunmayan oyuncunun şansı daha azdır.

Çin daması: Sayıları iki ile altı arasında değişen oyuncu ile oynanan Çin daması, halmadan türemiştir. Taş yerine bilye kullanılmaktadır. Her oyuncunun 10 ya da 15 taşı bulunmaktadır. Oyun yüzeyi altı köşeli bir yıldız biçimindedir ve üzerinde karelerin yerine küçük delikler bulunmaktadır².

\footnotetext{
${ }^{2}$ Ana Britannica Genel Kültür Ansiklopedisi: Cilt 6.
} 


\subsection{Dama oyununun tarihçesi}

Mısırda bulunan kalıntıların incelenmesi sonucu oyunun M.Ö. 1600`lere kadar geri gittiği belirlenmiştir. Plato, damanın kökeni üzerine düşünceler ileri sürdüğü ve Homeros'un Odysseus'da, Penelope'yi dama oynarken betimlediği bilinmektedir (Baykur, 2008, 15).

Pollux, Onomastikon adlı eserinde polis adı ile anılan bir oyundan söz etmektedir. Eserde, karelere bölünmüş olan oyun tablasında iki farklı renkte oyun pulu bulunduğu ve hepsinin eşit değerde olduğunu belirtecek biçimde ortak bir adla anıldığı kaydedilmiştir. Kurke, buradan yola çıkarak belirtilen bu oyunun satrançtan çok damaya benzediği yargısına varmıştır (Salkım, 2008, 7).

Dama oyunu Batı'ya Haçlı seferleri sırasında getirilmiş, 13.y.y.'dan başlayarak alkerk adı altında bütün Avrupa'da büyük bir ilgi görmüştür ${ }^{3}$.

Dama oyununun Osmanlı dönemine ilişkin yazılı kaynak, nadiren bulunmakta; veriler, farklı kaynaklar içinden parçalar halinde toplanarak; ortaya çıkan genel resim izlenebilmektedir. Bir Osmanlı vatandaşı olan Matbaacı Arakil Efendi, Hicri 1305 yılında (Miladi 1888) Faydalı ve Eğlenceli Oyunlar adında iki küçük dama kitabı yayınlamıştır (Görsel 1). Oyunların, Osmanlıca harflerle ve çizimlerle (Görsel 2) gösterildiği bu kitap (Çiftçi ve Güldeste, 2015, 1), Türk dama oyunu tarihindeki ilk kitap örneklerinden olması nedeniyle önemlidir.

Sonrasında dama üzerine yazılan, çoğunlukla; oyun, hurda ya da açmazların dama ustalarından toplanması ve görselleştirilmesi ile oluşturan basılı kaynaklar yazılmıştır ${ }^{4}$.

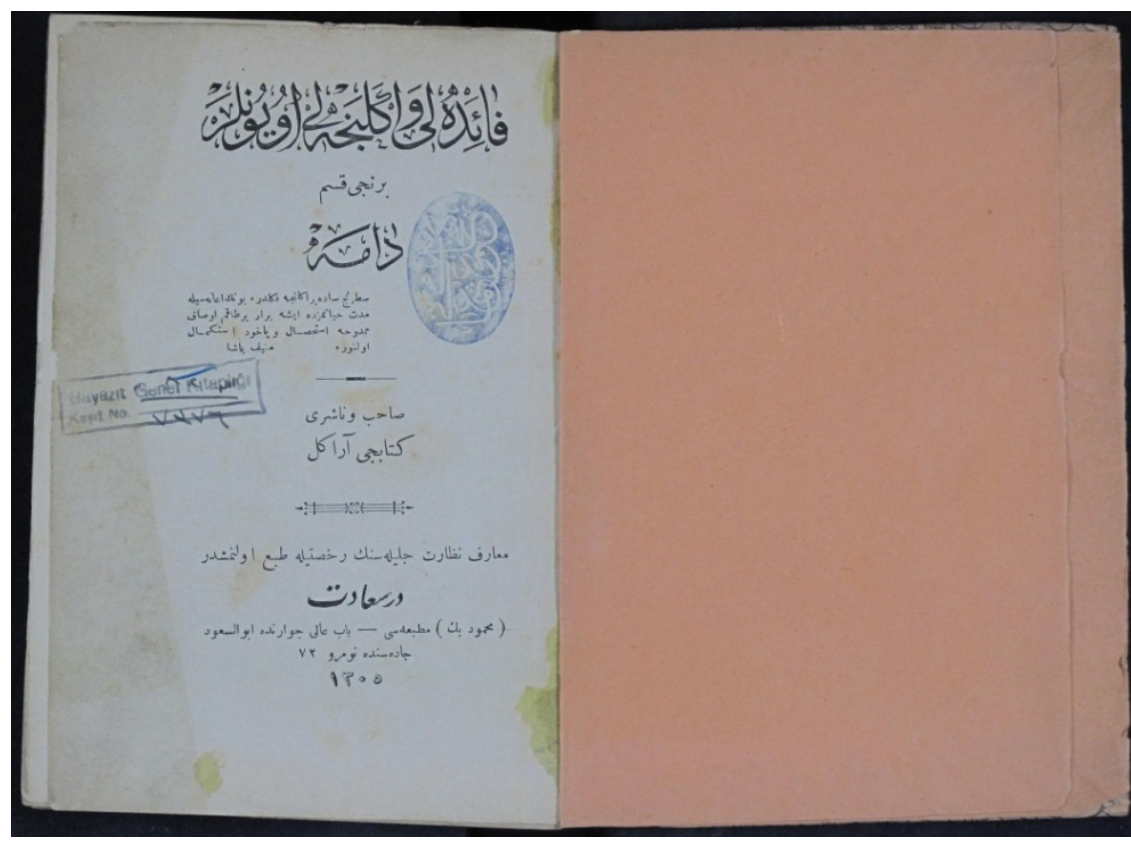

(Görsel 1: Güldeste, 2015)

\footnotetext{
${ }^{3}$ Büyük Larousse - Sözlük ve Ansiklopedi: Cilt 6.

${ }^{4}$ Ali Erdoğan Örnek'in Dama (1974), Özden Özsarı'nın Dama Kitabı (1988) Ali Ulusoy'un hazırlamış olduğu Osmanlı Döneminden Günümüze Dama (2009) adlarını taşıyan kitapları örnek olarak verilebilir.
} 


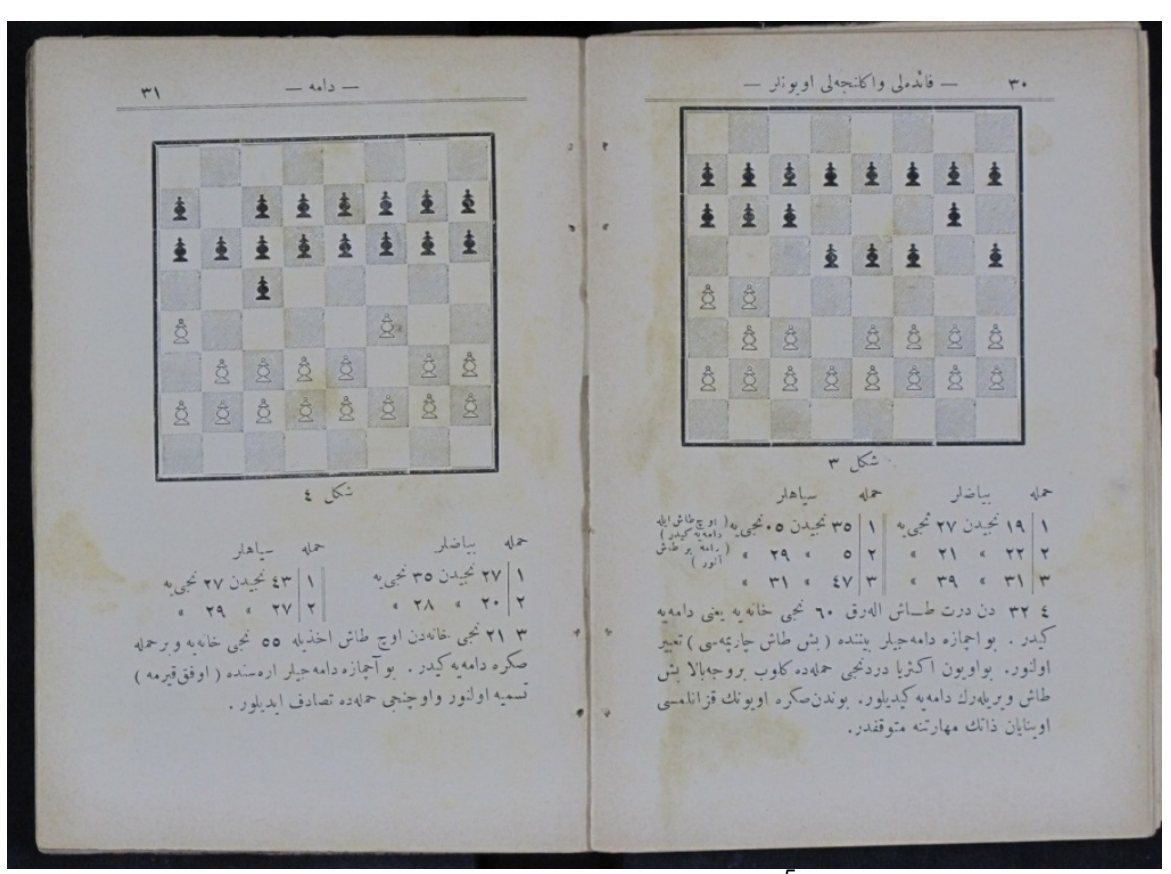

(Görsel 2: Güldeste, 2015)

Günümüzde de bu kaynaklar, gözden geçirilerek yeni oyunların eklenmesiyle yeniden basımı yapılmaktadır. Ancak burada dikkat çekilmesi gereken önemli bir nokta kaynaklarda yer verilen oyunların 100 yılı aşkın olmasıdır. Bu durum aslında dama oyuncularının her hangi bir sivil örgütlenme olmaksızın bu kültürel birikimi kendi aralarında ne denli büyük bir başarıyla sakladıkları ve geleceğe aktarmak için çaba harcadıklarını da göstermektedir.

Kaynaklardan Osmanlı döneminin damacılarının yüksek yetenekli kimseler olduğu öğrenilmektedir. O zamanlarda usta ve oyun sahibi olan damacılar bir besteci, bir ressam veya bir yazar kadar değer görmekteydi (Örnek, 1974, 18). Osmanlı döneminde dama oyunu en parlak zamanını Sultan Abdülaziz döneminde yaşamıştır. Padişah tarafından pek çok damacı saraya davet edilmiş ve saray kadrosuna alınmıştır. Damacı İbrahim Bey dönemin tanınan damacısıdır. Kasımpaşa'da esnaflık yaparken yeteneği ile padişah tarafından fark edilerek "Damacıbaşı" unvanı verilen İbrahim Bey, sarayda kendisine yer bulmuştur. Sultan Abdülaziz'in de iyi bir damacı olduğu ve dama literatüründe kendisine ait oyunlarının bulunduğu bilinmektedir (Baykur, 2008, 17).

Refi' Cevat Ulunay, gazete yazılarında dama kültürüne ilişkin önemli bilgileri kayıt altına almıştır. Milliyet Gazetesi'ndeki "Takvimden Yaprak" adlı köşesinde Sultan Abdülaziz'in damaya duyduğu ilginin, halk arasında da oyuna ilginin artmasına neden olduğundan ve böylece güçlü damacıların yetiştiğinden söz etmektedir. Buna ek olarak, dönemin tanınan damacılarından; Ethem Efendi, İbrahim Efendi, Haçik Efendi, Ziya Bey, Karamanlı Peynirci Bodos Ağa, İsmet Molla, Eyüplü Mürvet Efendi ve Limoncu Tatar Hüseyin'in adlarını vermektedir (Ulunay, 1967, s.n.y.).

Burhan Felek, Cumhuriyet Gazetesi'ndeki köşesinde İstanbul Aksaray'da henüz yerleşme yoğunluğu olmadığı dönemde çok sayıda damacı kahvesinin olduğundan söz ederek; Eminönü'nde bulunan ve iş sahiplerinin görüşmelerini yaptıkları Valde

\footnotetext{
${ }^{5}$ Matbaacı Arakil'in yazmış olduğu kitaba ilişkin görseller (Görsel 1), (Görsel2) Hasan Çiftçi ve Bektaş Güldeste tarafından hazırlanan, Osmanlı Döneminden Günümüze Kadar Ulaşan Türk Daması Açmaz Oyunları Güldeste adlı çeviri metinde bulunmamaktadır. Bu görseller, Bektaş Güldeste'den 2015 yılında yapılan görüşmeden sağlanmıştır.
} 
Kıraathanesi'nin dama oyuncularının toplandığı bir yer olduğunu belirtmektedir (Felek, 1959, s.n.y.).

Dama oyunu her ne kadar kahvehanelerin yarattığı kültür çevresi içinde oynanmakta ise de bu tür erkek egemen mekânlara giremeyen kadınların da damaya ilgi gösterdikleri bilinmektedir. Musahipzade Celal, "Eski Istanbul Yaşayışı" adlı eserinin İçtimai Hayat başlıklı bölümünde dama satranç, tavla, peçiç, minkale gibi oyunların erkekler kadar kadınlar tarafından da oynadığından söz etmektedir (Celal, 1946, 104). Topkapı Sarayı'nda yer alan haremde, sıradanlaşan yaşama canlılık katabilmek amacıyla meddah, karagöz ve orta oyuncularının gösterilerine yer verildiği ve haremde bekiz, kös ve sürme gibi oyunların oynandığı bilinmektedir. 19. yüzyıldan sonra bunların arasına tavla, domino ve dama oyunu da eklenmiştir (Akgündüz, 2002, 343).

Osmanlı Anadolu'su dışında Türk kültürünün egemen olduğu Kıbrıs'ta da damanın varlığı kayıtlarda geçmektedir. Osmanlı döneminde Lefkoşa'nın günlük yaşamında çok işlevli bir yeri olan kahvehanelerde dama, satranç ve bilardo gibi oyunların bulunduğu belirtilmektedir (Erdoğru, 2002, 642).

\subsection{Dama oyunu ve kuralları}

Türk daması, 38 kareden oluşan bir oyun yüzeyi üzerinde 16 taşla iki oyuncunun katıımıyla oynanmaktadır. Siyah ve beyaz olmak üzere iki renk taş vardır. Oyuncular, oyun tablasının kendi taraflarındaki ilk sırasını atlayarak taşlarını dizerler ki, bu sekizinci sıradır. Oyun sırasında taşlar, bir kare atlayarak sağa, sola ve ileri gidebilirken; geriye doğru ve çapraz yönde gidilemez. Oyunu, rakibin tüm taşlarını alan kazanmaktadır ve oyundaki tüm hamleler bu amaç üzerine kuruldur. Dama oyununda yoz ve dama adı verilen iki taş bulunmaktadır; bu isimler taşın oyun yüzeyi üzerindeki konumundan kaynaklanmaktadır. Yoz taş, dama kurallarıyla sınırlı bir şekilde hareket etmekte olan tüm taşlar için geçerli bir tanım iken, sekizinci kareye erişen ve serbest hareket yeteneği kazanan taşa dama taşı denmektedir. Kurallar ayrıntılı olarak belirlenmesine karşı genel olarak şu ana ilkelerin tüm kurallara egemen olduğu görülmektedir:

Oyuncu, taş alma konumuna geldiği anda veya rakibin gözden çıkardığı taşı almak zorundadır. Bir oyuncunun taş alırken az taraftan değil çok olan taraftaki taşları alması gerekmektedir. Eğer iki tarafa yapılacak olan hamlelerle eşit sayıda taş alma olanağı var ise istediği yönden taş alabilir. Yoz taş damaya çıkan bir doğrultuda bile olsa, yoz mutlaka çevresinde bulunan uygun konumdaki taşları da alarak damaya çıkmalıdır (Güldeste, 2015, 8).

\subsection{Damada tekniklerin ve oyunların adları}

Dama oyun kültürünün en çarpıcı yönlerinden biri de oyunların adlandırılmasıdır. Bu oyun ve tekniklere uygun görülen adlar çok ilgi çekici olabilmektedir. Bazılarına burada, yer verilmiştir. Bu oyunların bazılarının neredeyse 100 yılık; hatta daha fazla geçmişi bulunmaktadır. Yakın zamanda bir birlik çatısı altında resmi bir örgütlenme içerisine giren dama topluluğunun, bu oyunları günümüze kadar koruyup yazılı hale dönüştürmüş olması, bu kültürel bağın ve grup bilincinin ne denli yüksek olduğunu göstermektedir.

Ayıbacağı, Mekik tekniği, Makas tekniği, Takoz tekniği, Merdiven tekniği, Çarpma tekniği, Kocaoyun (Ortaoyunu), Çekme, Altıtaş, Manisalı, Topal, Kurtulmaz, İğneli baskı, Kasadar (Papaz kırması), Edirne açmazı, Konyalıoğlu açmazı, Dişi Baltacı Oyunu, Erkek Baltacı oyunu, Eşirme oyunu, Kapıcızade açmazı, Gezdirme oyunu, 
Demirci Kesmesi oyunu, Acem Baltası oyunu, Oda başı oyunu ya da Meşhur açmaz, Yusuf Kaptan veya Gemici açmazı, Has İmrahor (Çiftçi ve Güldeste, 2015, 2) gibi sayısız oyun bulunmaktadır.

\subsection{Dama oyunu ile ilgili bazı kavramlar}

Burada bazı kavramlara yer verilmekle beraber oyun içindeki kurallarla olan ilişkileri de belirtilmiştir. Bunun nedeni, bu kavramların aynı zamanda bir görenek ve gelenek içinde de yer bulmasından; yaşayan, canlı söyleyişler olmasındandır. Dama oyunu açılış hamleleri, oyun ortası ve oyun sonu tekniklerinden oluşmaktadır. Aşağıda belirtilen bu kavramlar oyunun farklı aşamalarında yer alabilmektedir.

Damaya çıkmamış taş olan taş Yoz Taş olarak adlandırılmaktadır. Bir ya da birkaç taş vererek damaya gitmeye Açmaz denir. Bir diğer adı da oyuna gitmedir. Bu açmazların çeşitleri bulunmakla beraber, oyunu yapanların adları ile anılmaktadır (Örn: Sultan Mahmut Açmazı). Oyunda sık kullanılan bir kavram olan Hurda, oyun sonunda az taşla oyuna gitme olarak kullanılmaktadır. Gayyım, her oyuncunun birer taşı kalması ya da beraberlik amacıyla kullanılmakta olan bir kelimedir. Turnuvalarda oyuncuların birbirine kayyım teklifi yasaklanabilmektedir. Taş kesişme (kırışma), taşların karşılıklı hamlelerle alınmasıdır. Damaya çıkmak, 8. sütuna gelerek oyunda hareket yeteneği artan taşın adlandırılmasıdır (Güldeste, 2015, 15).

\subsection{Dama oyuncularının takma ad kullanma kültürü}

Öncelikle dama oyuncuları arasında grup bilincinin çok yüksek olduğunun belirtmek gerekmektedir. Bunun bir yansıması olarak tüm Türkiye çapında dama topluluğunun sıkı olan bağları oyuncuların ve ustaların birbirlerini takma adlarla çağırmalarına neden olmuştur. Çoğunlukla turnuvalarda ya da dama oyunu oynanan ortamlarda oyuncular birbirlerini adlarından çok lakâpları ile anmaktadır. Belirlenenler şunlardır:

Mürşit Ersöz (Hamleci Hurşit), Hüseyin Öner (Tankçı), Hüseyin Kaygısız (Saddam), Çetin Özyılmaz (Albay), Osman Pıtır (Osman Baba), A. Kadir Benzer (Bayraklı Şampiyon), Süleyman Babi (Babi), Murat Keser (Boşnak Murat), Ahmet Karadaş (Kumaş Ahmet), Hayri Çakır (Dişçi Hayri), Ramazan Akçagül (Bucalı Ramazan) ${ }^{6}$.

\section{KAHVEHANE}

Kahvehaneler Anadolu topraklarının en eski kurumlarından biridir (Çağlayan, 2012, 96). Dolayısıyla toplumsallaşma çabalarının ve etkinliklerinin köklerini bu kurumdan başlatmak yerinde bir yaklaşımdır. Kahvehanelerin Türk sosyokültürel yaşamı içinde yer almaya başlamadan önce Müslümanların toplu halde bir araya geldiği açık sosyal mekânlar cami, tekke, hamam ve bozahanelerdi. Hamamlar, sosyalleşme mekânları olarak; işlevleri sınırlı olduğu gibi bir ölçüde pahalı bir zevkti. Bozahaneler ise bozanın içinde çok az miktarda da alkol olduğu düşüncesi nedeniyle hoşgörülmemekteydi ve toplumsal bakış açısı olarak gayrimüslimlerin meyhanelerinden de daha itibarlı yerler değildi (Çobanoğlu, 1999, 58). İlk kez cami yakınlarında namaz saatini bekleyen kişilerin zamanlarını doldurmalarını sağlamak amacıyla ortaya çıkan bu mekânlar, kahvenin büyük ölçeklerde tüketimi nedeniyle, caminin bir yan yapısı olmaktan kurtulup, kendi özgün işlevini kazanmıştır (Çağlayan, 2012, 103). Kahve tüketiminin toplumda yerleşmesi ile birlikte kahvehanelere devam eden kitle de bu mekânları sosyalleşme gereksinimlerinin çevresinde dönüştürmeye başlamıştır. Bu süreçte

\footnotetext{
${ }^{6}$ Adları verilen kişilerin kullandıkları takma adlara ilişkin bilgi, İzmir'de 2013 yılında, A. Kadir Benzer ve Ramazan Akçagün ile yapılan görüşme ile sağlanmıştır.
} 
özellikle ulemanın ve siyasi yönetimin başlangıçta büyük bir tepki ile karşısında durdukları kahve ve kahvehane ile barışmasının önemli bir etkisi olduğunu da belirtmek gerekmektedir.

Günümüzde kahvehanelerle ilgili olarak geçerliliğini sürdüren olumsuz yargılara karşıt olarak; özellikle Osmanlı dönemi kahvehanelerinde kültürel anlamda çok canlı bir yapının olduğu görülmektedir. Kahvehaneler içeriksiz konuşmaların yer bulduğu mekânlar olmaktan çok toplumsal siyasi ve kültürel sorunların tartışıldığı ve yoğun edebi etkinliklerin oluştuğu mekânlardır. U. Kömeçoğlu'nun aktardıklarına göre, Peçevi, kahvehane ziyaretçilerin bir bölümünün kitaplar, risaleler ve lirik şiirler okuduğunu, bazılarının satranç ve tavla oynadığını, bazılarınınsa edebiyat konuştuğunu belirtmektedir. Kahvehanelerin hatiplerinin olduğundan ve onların söylevlerini hayranlıkla izleyen müşterilerin bulunduğundan söz etmektedir. Işın ise mahalle kahvelerinin küçük halk kütüphaneleri olarak hizmet gördüğünü ve burada özellikle dini kitaplar ve halk destanlarının okunduğunu ve dinlendiğini belirtmektedir (Kömeçoğlu, 2010, 57).

Ancak ilerleyen zamanlarda, yeniçerilerin Osmanlı toplum yaşamının içinde yer almaya başlamasıyla açılan yeniçeri kahvehanelerinin, gittikçe denetimden çıkmaya başlaması, devlete karşı olan kalkışmalarda bir karargâh gibi kullanılması; öte yandan mafya tipi bir yapılanmaya gitmeleri, Osmanlı yönetiminin büyük bir baskınla bunları kapatması ile sonuçlanmıştır. Bununla birlikte devlet sohbeti adı verilen siyasi dedikoduların kahvehanelerdeki günlük konuşmaların odağında olması, yönetim tarafından buraların izlenmesine ve konuşulan tüm konuların jurnaller altında toplanmasına yol açmıştır. İ. Ortaylı, geleneksel toplumlarda da kamuoyunun oluştuğu yerlerin bulunduğunu belirterek; kahvehanelerin ve meyhanelerin kapatılmasının tütün ve içki düşmanlığından değil, devlet sohbeti olarak adlandırılan ve bu mekanlarda bolca yapılan siyasi dedikoduyu önlemek amacıyla olduğundan söz etmektedir (Gül, 2006). Bu çalkantılı süreç içinde kahvehaneler özellikle, 19'y.y.daki değişim furyasından etkilendi. Bu dönemde yeni kahvehane türleri artık İstanbul'da boy göstermeye başladı. Geleneksel Türk kahvehanesinin çeşitlenmesi kadar özellikle Pera ve Galata'da açılan daha Batılı anlamdaki kafeler de görülmeye başladı. Bu süreç içinde gittikçe çeşitlenen kahvehaneler, Batılı anlamdaki örneklerinin karşısına yeni biçimlerle çıkmaya başlamıştır (Georgeon, 1998, 63).

\subsection{Dama kahvehaneleri}

İstanbul'da kahvehanelerin ilk açıldığı günden itibaren devam eden süreç içerisinde kahvehaneler ayrışmaya başlamış, toplumsal işlevi müşterisine göre şekillenmiştir. Pek çok farklı türün oluştuğu kahvehaneler erkek egemen karakterini korumuş ve erkek sosyalliğinin çekim merkezi olmuştur (Emeksiz, 2009, 127). Doğu kültüründe kulüp ya da derneklerin gelişmemesi nedeniyle toplumsallaşmanın mekânı kahvehaneler olmuştur. Bu nedenle konu değerlendirilirken dama kültürünün de böyle bir çevrenin ürünü olduğunu ve bunun içinde geliştiğini belirtmek gerekmektedir.

Kahvehane tüm işlevlerinin yanında bir de toplumsal ortam olarak önemli bir iletişim noktasıdır. 19. yüzyıl sonlarına kadar İstanbul'da gazete ve benzeri iletişim araçları bulunmuyordu. Zaten okuryazar oranın çok düşük olduğu bir toplumda da böyle bir istem de oluşmuyordu. Ancak toplumun söylenti ve dedikodu üzerinde yürüyen sıkı bir iletişim ağı vardı ve bu ağın merkezinde kahvehane yer almaktaydı. Yalnızca içeceğin tüketilmesi ve salt toplumsallaşma gereksiniminin ötesinde yeni haberleri öğrenmek için bulunmaz bir olanak oluşturan bu yapıların, temel bir tip olan mahalle kahvehanelerinde görüldüğü üzere iletişim ağının merkezinde olma özelliği (Sökmen, 2011, 40), kuşkusuz dama kültürüne ilişkin tüm bilgi birikiminin de bu çatı altında 
korunmasını ve oyuncu kuşakları arasında aktarılarak günümüze kadar gelmesini sağlayan en önemli etken olmuştur.

Dama kahvehaneleri, doğrudan ele alınmamakla beraber; çeşitli kaynaklarda, özellikle kahvehanelerin genel tarihinden söz eden toplumsal ve tarih içerikli yazılardan dama oyunun yer aldığı mekânlara ilişkin veriler toplanabilmektedir.

Osmanlı döneminde damacıların devam ettiği dama kahvehanelerinin arasında Selimiye'de yer alan Çiçekçi Kahvesi ve Fatih Çarşamba da yer alan Çavuş'un kahvesi sayılmaktadır. Özellikle, Çiçekçi Kahvesi'ne Abdülaziz'in seryaveri olan Halil Paşa'nın emekliğinin ardında devam ettiği bilinmektedir (Ulunay, 1964). Dama oyunu yalnızca özelleşmiş kahvehanelerde değil; pek çok kahvehanede de yer bulmaktadır. İstanbul Fatih semtinde bulunan Mahmut Paşa Camii avlusunda satranç yanında dama oynanmaktadır. Bu kahvehaneye yalnızca yazarlar, ozanlar, bilginler gelmektedir (Birsel, 2009, 203). Süleymaniye'de bulunan Tiryaki Çarşısı kahvehaneleri de zamanın kültürlü kişileri tarafından ziyaret edilen mekânlardır. Buralarda damanın da aralarında bulunduğu oyunlar oynanmaktadır (Birsel, 2009, 189).

Günümüzde Türkiye'nin pek çok yerinde dama kahvehaneleri bulunmaktadır ve bu sayı artmaktadır. Dernekleşen dama oyuncuları yakın çevre ilçelerde de dama kahvehanelerinin açılmasına gayret göstermektedir. Bu yazı hazırlanırken ülke çapında dama oyuncularının aralarında etkin bir biçimde işleyen iletişim ağından yararlanılmıştır. Ziyaret edilen kahvehanelerdeki dama oyuncularının verdikleri bilgiler değerlendirilmiş ve mekânlar incelenmiştir. Aşağıda bu kahvehanelerin bazılarına yer verilmekte ve bu mekânlar üzerinden dama kahvehaneleri incelenmektedir.

\section{DAMA KAHVEHANELERI İÇ MEKÂN KURGUSU}

Türk toplumsal yaşamının gerçekleştiği başat bir mekân olan kahvehanelerin, resim sanatından, edebiyata ve tarih yazımına kadar geniş bir alanda betimleme geleneği bulunmaktadır.

Süheyl Ünver, Türkiye'de Kahve ve Kahvehaneler adlı eserinde değerli bilgileri yazı ile kayıt altına aldığı gibi, Türk ve yabancı sanatçıların desenlerine ve eserlerine de yer vererek o dönem kahvehane iç mekânları üzerine bilgi vermiştir (Ünver, 1963).

Öte yandan insan-mekân ilişkisinin ele alındığı bu mekânların betimlenmesinde, Türk ve yabancı yazarların ve sanatçıların eserleri kadar gezginlerin katkısı çok önemli olmuştur. Bu nedenle, Batılı yazarların Osmanlı ülkesine yapmış oldukları gezilerdeki izlenimlerini yazdıkları seyahatnamelerden elde edilen bilgiler de önemli bir kaynak oluşturmaktadır. Ancak kayıtlar, daha çok kahvehanelerde gerçekleşen eğlencelere ve bir Batı gezgin için egzotik bulunan konulara dikkat çekmektedir. Benzer bir durum, Osmanlı dönemi kahvehane mimarisine ve iç mekân örgütlenmesine ilişkin ayrıntılı bilgiler içeren gravürler için de geçerlidir. Ancak bu betimlerden birçoğu hayali bir kurguya dayanmaktadır. 19. yüzyıl öncesine ait kahvehanelerden günümüze kadar herhangi bir mimari yapı kalmaması nedeniyle 19. yüzyıl sonlarına ve 20. yüzyıl başlarına ait kahvehane fotoğrafları ve Hoca Ali Rıza'nın çizimlerinden bu dönemlerdeki kahvehanelerin mimarisi üzerine bilgi edinilmektedir (Yaşar, 2010, 13).

Dama oyununun oynandığı kahvehanelerdeki mekân kurgusuna ilişkin genel ilkelerin belirlenebilmesi için Türkiye'nin farklı yerlerindeki kahvehaneler ziyaret edilmiştir. Bu kahvehaneler seçilirken dama oyuncularının önerileri doğrultusunda hareket edilmiştir. Türkiye çapına yayılmış olan dama topluluğunun birbirleriyle olan güçlü iletişim ağı kahvehanelerin ziyaretinde, bilgi alınmasında büyük bir kolaylık sağlamıştır. Ülkemizde 
damacılar bir araya gelerek kültürlerini korumak ve topluma aktarabilmek amacıyla dernekleşmeye çalışmaktadırlar. Ancak dernek için gerekli olan özel mekâna hepsi sahip değildir. Bu nedenle dama oyuncuları çoğunlukla kahvehanelerin içinde kendilerine yer bulmaktadırlar.

İncelenen mekanlara aşağıda alfabetik sıraya göre yer verilmiştir.

\subsection{Adana}

Dama oyunu, Adana'da pek çok kez adres değiştirmiştir. Oyun, 1960'lı yıllarda Dörtyol Ağzı İnönü Meydanı'nda Yüksek Kahve'de oynanmaktaydı. Özellikle 1965-90 yılları arası Büyük Saat'te bulunan Köylü Kahvesi'nin damanın gelişmesinde önemli bir yeri olmuştur. 90'lı ve 2000'li yıllar arasında Akdeniz Kıraathanesi'nden devam eden oyun, 2000'li yıllardan itibaren Denizli Mahallesi'nde bulunan Özmoda Kıraathanesi'nde oynanmaktadır ${ }^{7}$. Adana Damacılar Derneği, 2007 yılında kurulmuştur, ancak maddi olanaksızlıklar nedeniyle derneğin oyun salonu henüz bulunmamaktadır.

Dama oyuncularının kahvehane içinde yerleşmiş oldukları bölüm; oyun masası, sandalyeler ve ara birim olan sehpadan oluşan oyun biriminin yinelenmesiyle, doğrusal olarak oluşmuştur (Fot.1). Burada, diğer masa oyun türlerinin de yer aldığı plan yerleşimi içinde; dama oyun oynama kültürünün, mekân içinde yer seçiminde ve yerleşimdeki etkisi gözlenebilmektedir (Fot. 2).

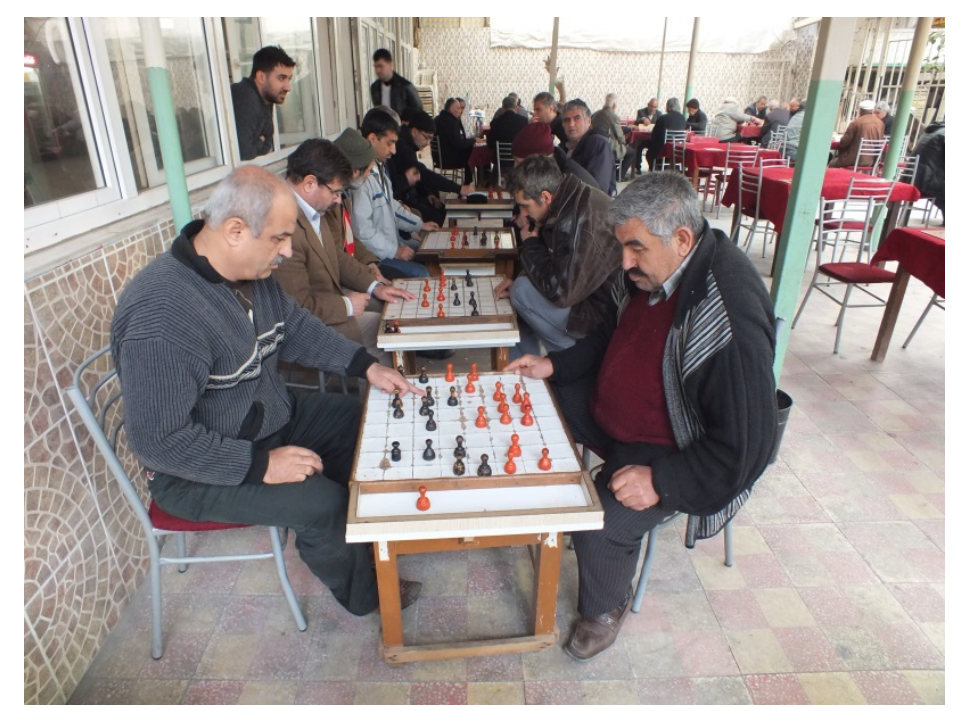

(Fot.1: Bülent Ayberk, 2014)

\footnotetext{
${ }^{7}$ Bu bilgi, Başta Adana Damacılar Derneği Başkanı Sabit Önal olmak üzere; diğer Adanalı damacılarla yapılan 2014 tarihli görüşmede sözlü olarak verdikleri bilgilerden derlenmiştir.
} 


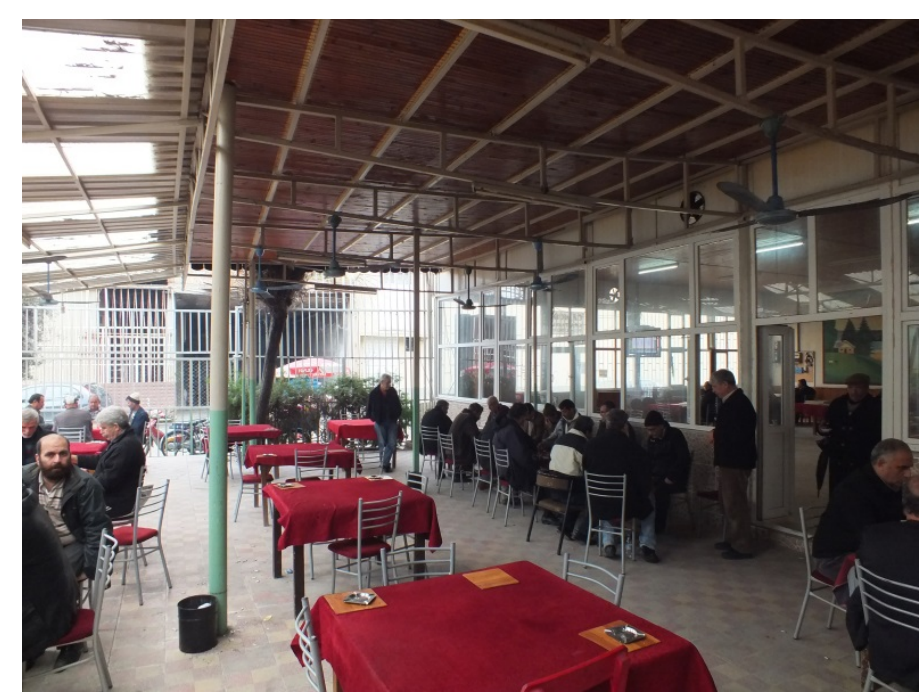

(Fot.2: Bülent Ayberk, 2014)

\subsection{Batman}

2013 yılında kurulan Dama Severler Derneği, Çarşı Mahallesi Eski Midyat Garajı, İşler Pasajı'nda bulunmaktadır. Kahvehane kare bir plana sahiptir. Dama oyunu için özelleşmiş bu mekân içerisinde dama masaları, diğer örneklere benzer biçimde doğrusal olarak yerleştirilmiştir. Duvarlar ahşap lambri ile kaplanarak oyuncuların bu yüzeyi yaslanmak amacıyla kullanabilmesi sağlanmıştır.

Yalnızca dama oynanan kahvehane kalabalık bir oyuncu kitlesine sahiptir. Doğrusal bir yerleşimin egemen olduğu bu planlama, oyun kültürünün etkisi ile ihlal edilebilmektedir. Rakip oyuncuları izlemek amacıyla toplanan izleyicilerin yoğun müdahalesi ve oyuna katıım alışkanlıkları dama masası merkezli toplanmalara neden olmaktadır (Fot.3). Bu durum, doğrusal dizilimin dağılmasına neden olabilmektedir.

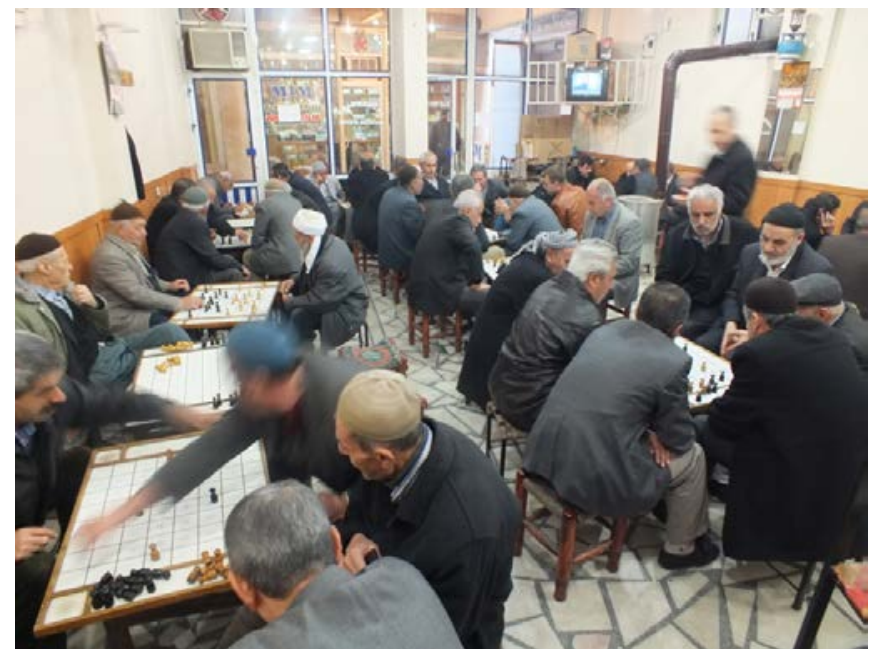

(Fot. 3: Bülent Ayberk, 2014)

\subsubsection{Batman'dan diğer kahvehane örnekleri}

Aşağıdaki görselleri verilen mekânlar, farklı türlerdeki masa oyunları yanı sıra dama oyuna da yer veren işletmelerdir. Özellikle doğu illerinde çok karşıllaşılan çayevlerinin böyle bir özelliği bulunmaktadır. Bu nedenle bu başlık altında toplanmışlardır. 
Batman'da dama oyunu oynanan kahvehaneler ve çayevleri damacıların federasyona gitmeden önce mesken tuttukları; özellikle katılacakları turnuvalar öncesinde antremanlarını yaptıkları yerler olmuşlardır (URL-1). Bu çayevi ve kahveler özellikle Kısmet Mahallesi eski Mehtap Sineması yakınında konumlanmaktadırlar. Günün her saatinde ve yoğun olarak hafta sonları dama oynayanların görülebildiği bu mekânlar özellikle Ramazan ayında iftar saatini bekleyenler için önemli bir zaman geçirme ve zamanı değerlendirme noktalarıdır (URL - 2).

Aşağıdaki görsellerde yer verilen Keklikçiler Kahvesi (Fot.4), Petrol Çayevi (Fot.5), Dostlar Çayevi'nde (Fot.6) gözlenebileceği üzere doğrusal ve noktasal yerleşim biçimi kullanılabilmektedir. Ayrıca oturma kültürünün biçimlendirdiği oturma mobilyası ve buna bağlı olarak oyun masası ile arasındaki biçimsel ve oransal ilişki bir dama oyun birimi tipolojisi ortaya çıkarmaktadır.

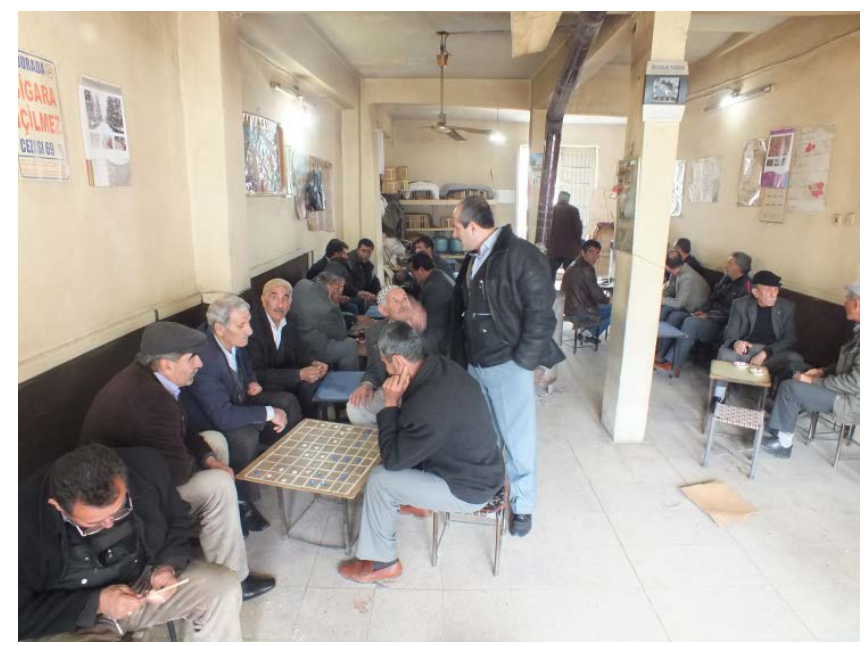

(Fot.4: Bülent Ayberk, 2014)

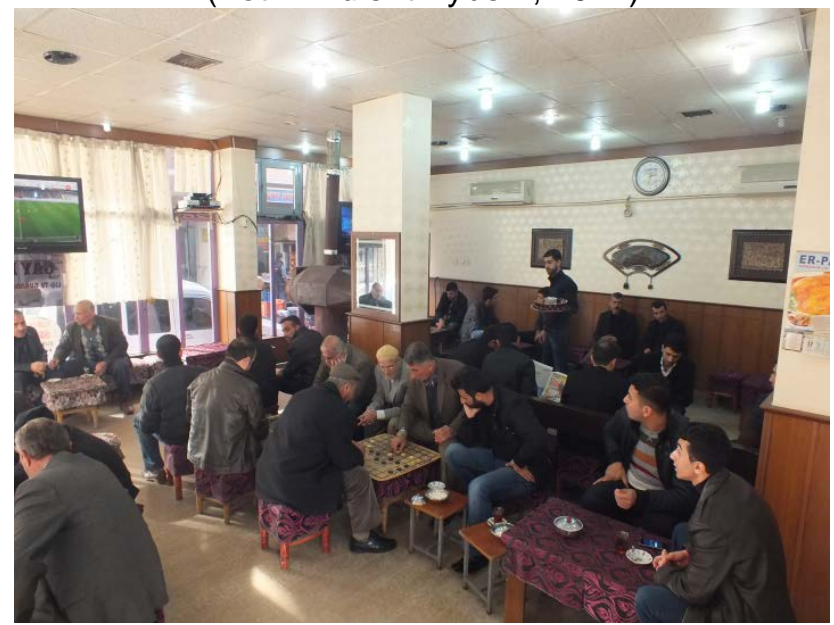

(Fot.5: Bülent Ayberk, 2014) 


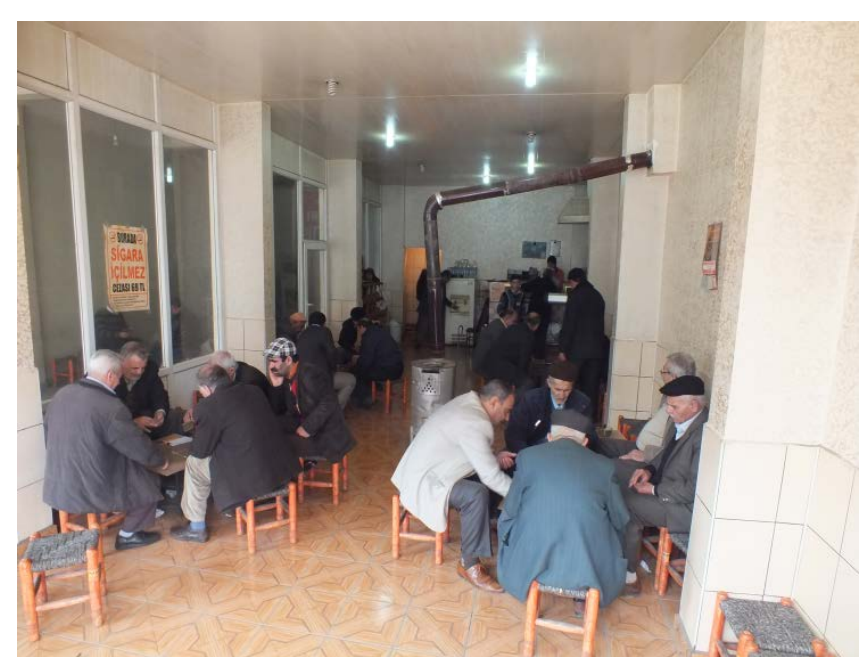

(Fot.6: Bülent Ayberk, 2014)

\subsection{Bursa}

Çoğunlukla Muş'lu Hasköy'lülerin devam ettiği bu kahvehane; bu yönüyle, kahvehanelerin hemşehrilerin toplandığı mekânlar olma işlevine güzel bir örnektir. Burada kullanılan dama masaları yaşlı oyunculara kolaylık sağlamak amacıyla alışılmış bir oyun masası boyutlarına ulaşmaktadır. Bu nedenle oyun masası mobilyası biçimsel olarak, mevcut kahvehaneler arasında benzerine rastlanmayan bu özelliğiyle, kahvehaneyi önemli bir konuma getirmektedir (Fot.7).

Planlamada masalar doğrusal değil, noktasal olarak yerleştirilmiştir. Duvarlar boyunca yerleştirilen, yerel söyleyişle ranza olarak adlandırılan, oturma elemanı, farklı bir oturma kültürünün mobilyası olarak dama kahvehanelerindeki oturma biçimine ve planlamasına yeni bir katkı sunmaktadır (Fot.8). Bu otuma biçimin etkisi özellikle Türkiye'nin doğusunda yer alan kahvehanelerde görülmektedir.

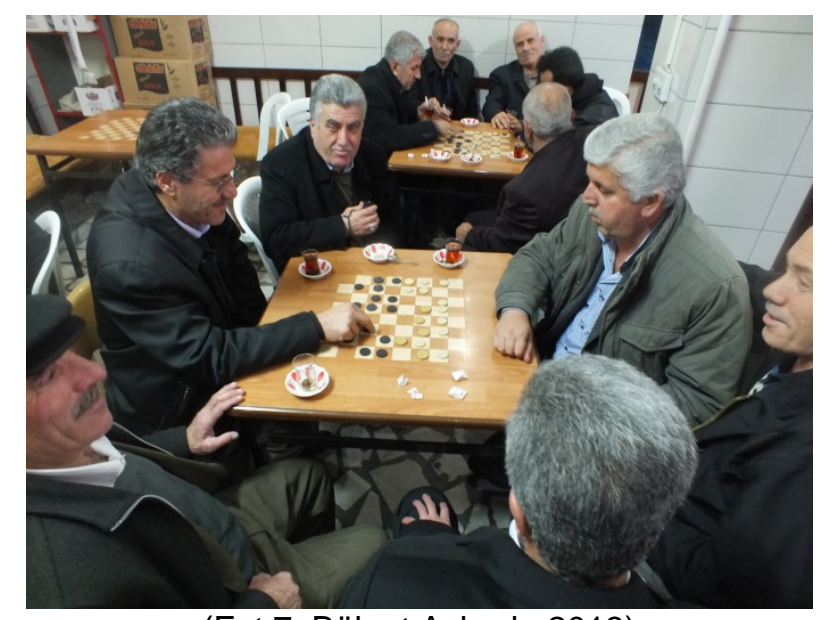

(Fot.7: Bülent Ayberk, 2013) 


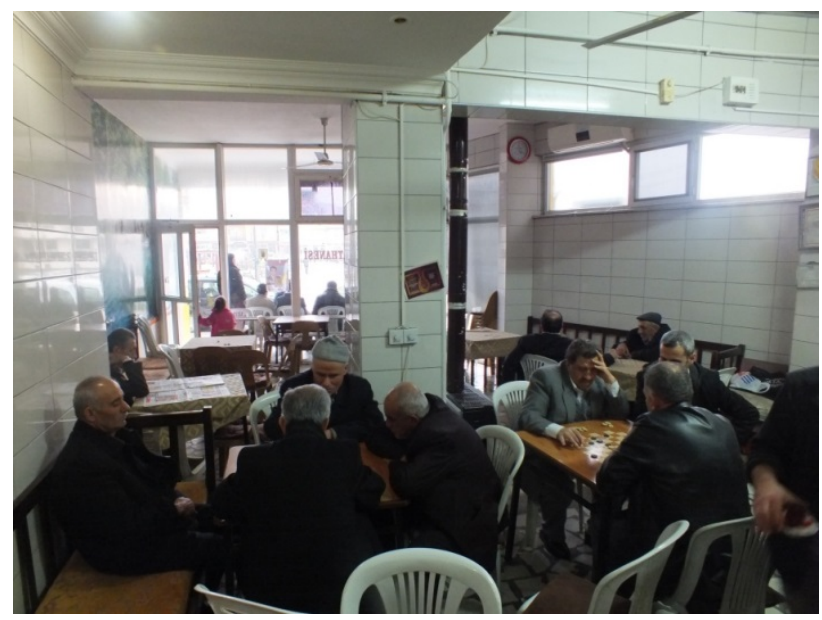

(Fot.8: Bülent Ayberk, 2014)

\subsection{Denizli}

Pelitlibağ Camii karşında bulunan Kırmızı Kahvehane'de dama masaları kahvehanenin bir bölümünde doğrusal olarak konumlandırılmıştır. Bu dama masalarının en önemli özelliği oyun yüzeylerinin mermerden üretilmiş olmasıdır. Benzer bir biçimde İzmirTilkilik semtine yakın bir konumda bulunan bir açık hava parkında da mermer dama masaları bulunmasına karşın; bu oyun masaları, metal konstrüksiyon yapısı ile dış mekan şartlarına dayanacak biçimde üretilmiştir.

Ancak benzerini diğer dama oynanan kahvehanelerde görme olanağı bulunmayan ve iyi bir mermer işçiliğinin eseri olan bu masaların, iç mekânda kullanılıyor olması, Kırmızı Kahvehane'yi önemli bir konuma getirmektedir (Fot.9).

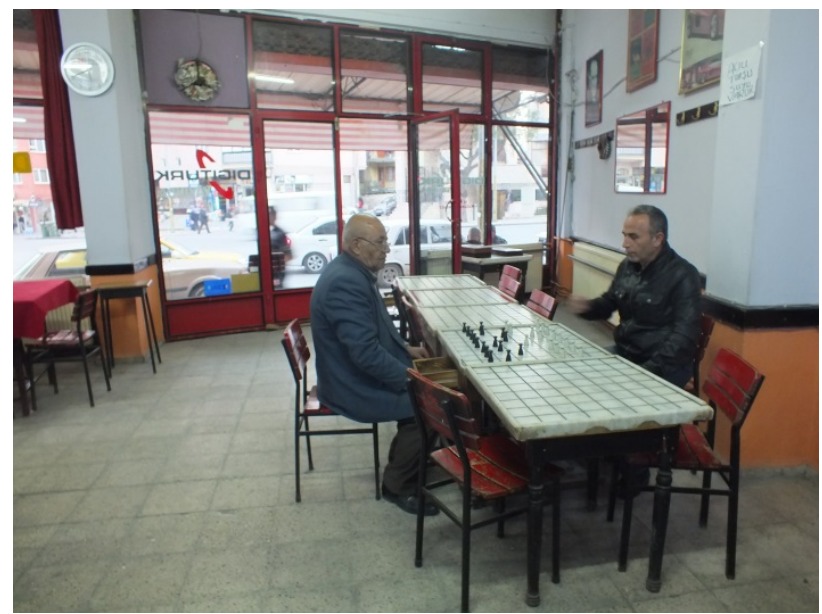

(Fot.9: Bülent Ayberk, 2013)

\subsection{Diyarbakır}

467. sokakta yer alan Yaşar Çay Evi'nde diğer dama oynanan mekânlardan farklı olarak doğrusal bir düzen değil; sehpanın etrafına konumlanan kürsülerle oluşturulan noktasal bir yerleşim görülmektedir. Bu oyun birimi, sehpalar ve kürsülerden oluşmaktadır. Aşağıdaki görsellerde görüldüğü üzere sehpa, üzerine konulan dama tablası ile bir oyun masasına dönüşmektedir (Fot.10). Geniş oyun mekânının duvarları boyunca yerleştirilen kanepelerle sehpa ve kürsü bir araya getirilerek yeni bir modül oluşturulmuştur. Bu birim, yukarıda Bursa'da bulunan kahvehanenin mekânı 
anlatılırken değinildiği üzere; halk arasında "ranza" olarak adlandırılan oturma mobilyasının ve oturma biçimi kültürünün (Fot. 8) günümüzde üretilen mobilyalarla karşılanarak oluşturulmuş bir yorumudur.

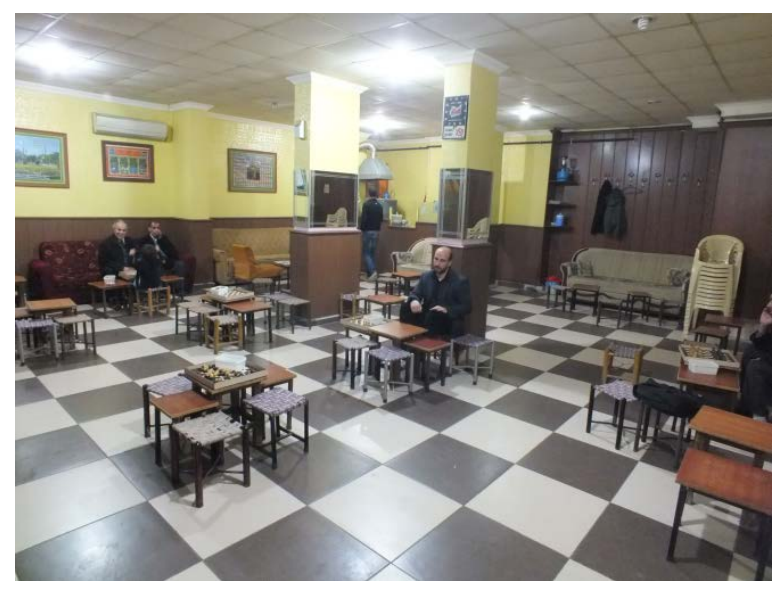

(Fot: 10: Bülent Ayberk, 2014)

\subsubsection{Diyarbakır'daki diğer kahvehaneler}

Aşağıda görseli verilen Yüksek Kahve (Fot.11), Ofis semtinde yer almaktadır ve dama oyuncularının uğrak yerlerindendir. Görseli verilen diğer bir mekân ise Garajlar Kahvehanesi'dir (Fot.12).

Doğu illerimizdeki kahvehanelerde kürsü olarak adlandırılan oturma mobilyasının yaygın kullanımı, dama masasının ölçülerini biçimlendiren başat etken olduğu gibi kullanıcı açısından da mekânla etkileşiminde belirleyici olmaktadır. Oturma mobilyası olan kürsüde sırt için yaslanma yüzeyinin olmayışı kullanıcılar açısından mekânın tüm duvarlarını ve ayırıcı yüzeyleri -pencereler gibi- yaslanma yüzeylerine dönüştürmektedir.

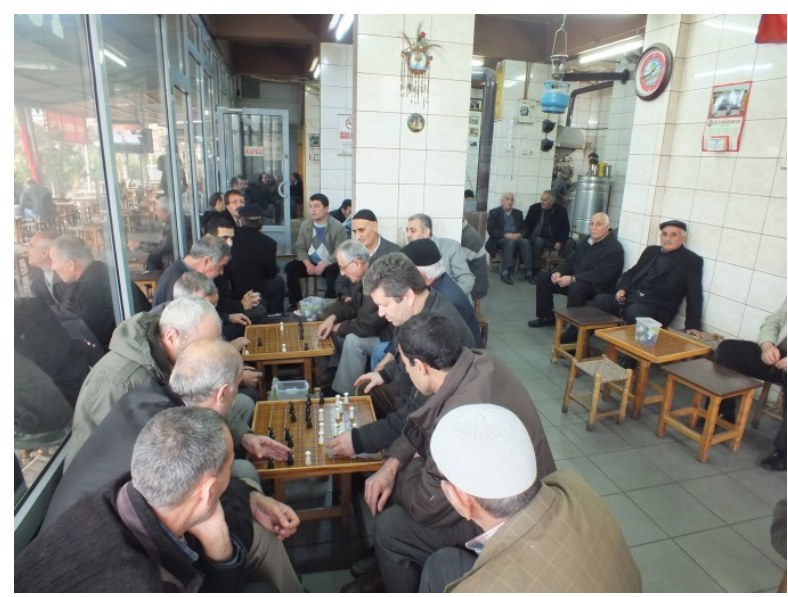

(Fot.11: Bülent Ayberk, 2014) 


\section{6. İstanbul}

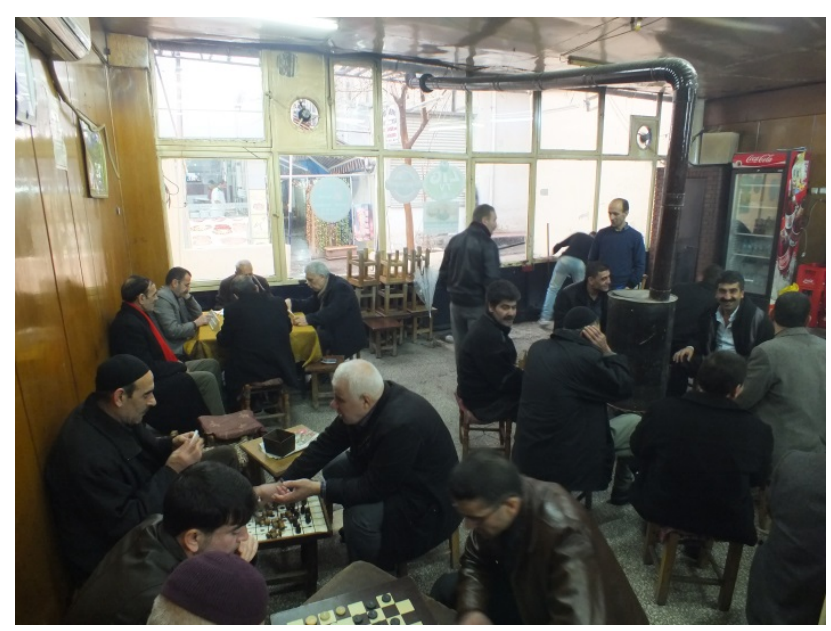

(Fot.12: Bülent Ayberk, 2014)

Dama oyuncularının İstanbul'daki merkezleri olarak gördükleri damacılar kahvehanesi, konum olarak Fatih Kadınlar Pazarı'nda Bozdoğan (Valens) su kemerinin hemen dibinde bulunmaktadır. Yakın çevrede başka dama oynan kahvehaneler bulunmasına karşın; bu kahvehane özellikle usta oyuncuların geldiği bir mekândır.

Kahvehanenin uygun mevsimlerde kullanılan dikdörtgen plana sahip bir açık alanı ve aşağıda görsellerine yer verilen kapalı mekânı bulunmaktadır. Doğrusal olarak bir araya gelen dama masaları, mekânın kullanımını etkileyen en önemli etmendir (Fot.13).

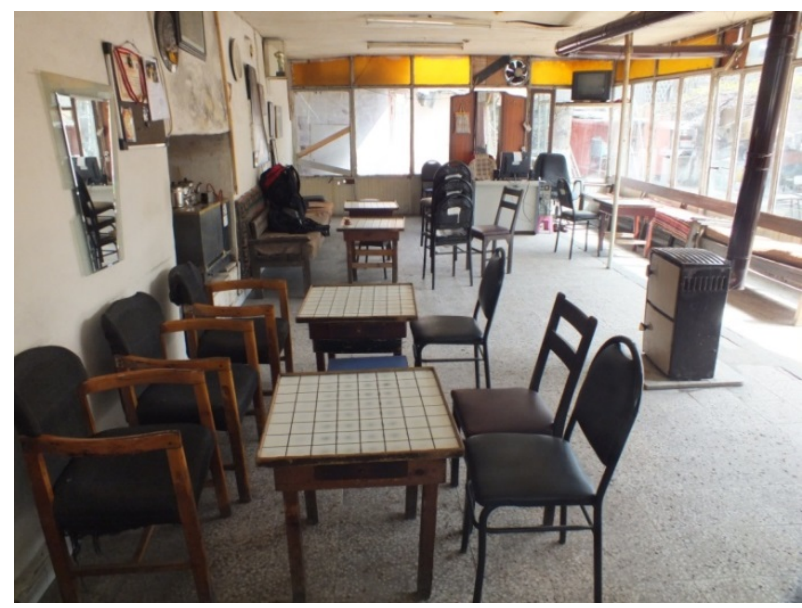

(Fot.13: Bülent Ayberk, 2012)

Türkiye'nin pek çok yerinden gelerek İstanbul'a yerleşen yurttaşların dama oynadığı bu mekânda - oyuncuların kültür ve beden ilişkisinden kaynaklanan farklı oturma alışkanlıklarına karşın - oturma birimi olarak sandalye kullanılmaktadır (Fot.14). Bu birim, mekândaki oyun masasının yükseklik ve genişlik ölçülerini etkilemesi bakımından da önemlidir. Sandalye kullanımı ile birlikte antropometrik ve algısal gereksinimler oyun masasının da oranlarını farklılaştırmıştır. 


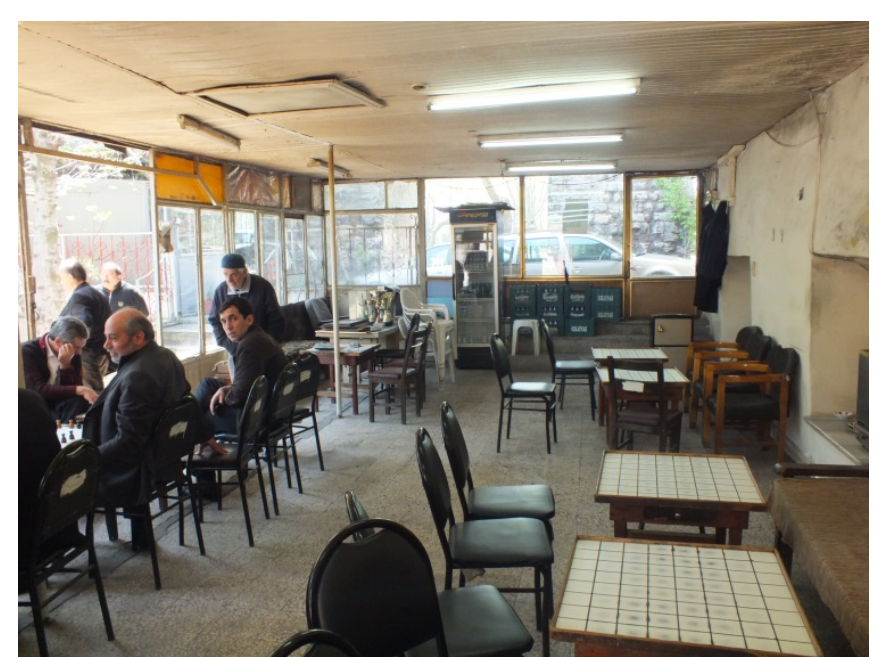

(Fot.14: Bülent Ayberk, 2012)

\section{7. İzmir}

Konak ilçesi sınırları içerisindeki Eşref Paşa semtinde bulunan damacılar kahvesi özelleşmiş bağımsız bir mekân olarak değil; kıraathanenin bir parçası olarak kullanılmaktadır. İzmir'li usta dama oyuncularının uğrak yeri olan bu mekân, İzmir'li dama topluluğunun merkezi olarak kullanılmaktadır. Teras bölümü tüm mevsimlerde etkin olarak kullanılmaktadır (Fot.15).

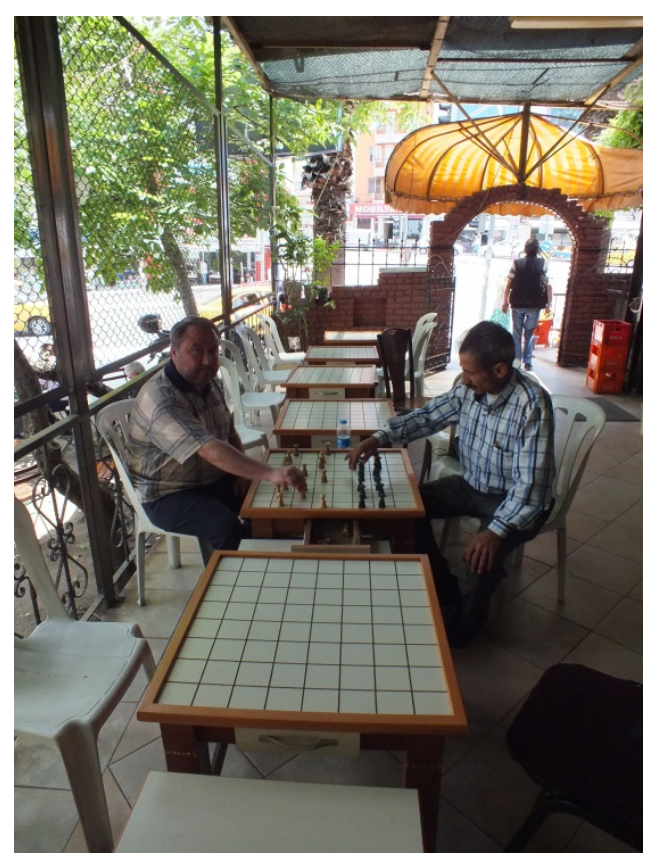

(Fot.15: Bülent Ayberk, 2012)

Dama turnuvalarının da düzenlendiği kıraathane, böyle zamanlarda yoğun bir oyuncu kitlesini ağırlamaktadır. Görsellerde görülen dama masalarının (Fot.16) turnuva zamanlarında sayıca yetersiz kalması nedeniyle İzmir Damacılar Derneği tarafından yaptırılan taşınabilir dama oyun yüzeyleri (Fot.17), var olan diğer oyun masalarının üzerinde kullanılmaktadır. Bu durum birbirinden farklı kullanım biçimlerini bir araya getirmektedir. 


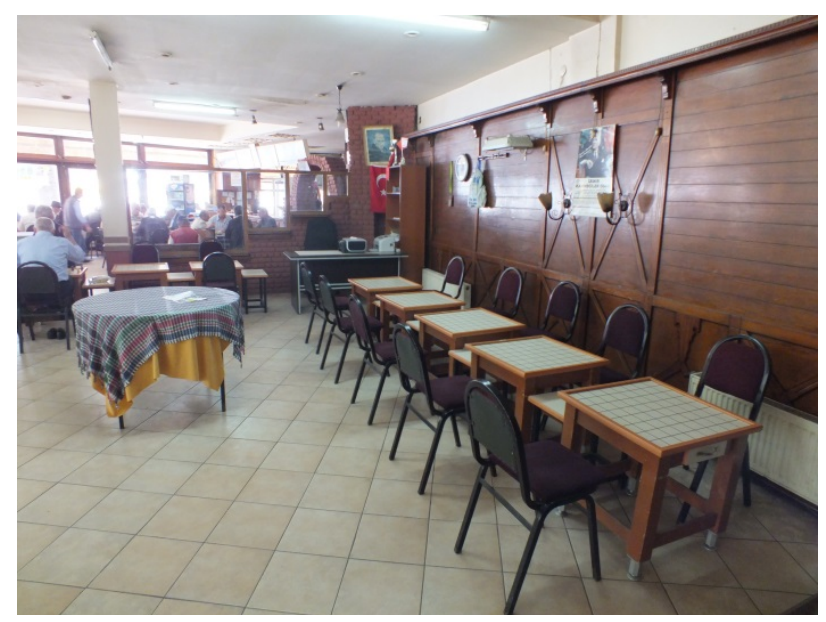

(Fot.16: Bülent Ayberk, 2012)

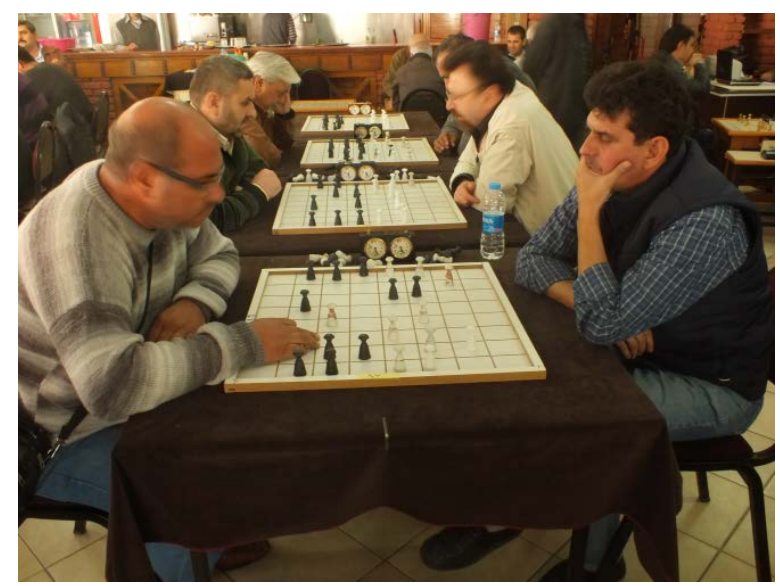

(Fot.17: Bülent Ayberk, 2014)

\subsection{Karşıyaka}

Kahvehanenin eğimli olan cephesi, iç mekânda plana özel bir biçim vermektedir. Dama masalarının dizilişini de etkilemekle beraber hemen tüm kahvehanelerde görülen doğrusal yerleşim burada da görülmektedir (Fot.18). Pekçok kahvehanede yerleşim düzeni göz önüne alındığında dama masalarının diğer oyun türleri için kullanılan oyun masalarına göre ikincil bir konumda bulunmalarına karşın; burada plan düzeni içinde hiyerarşi açısından egemen bir konumda bulunmaktadırlar (Fot.19). Bu kahvehaneyi önemli bir konuma taşıyan bir diğer özellik; dama federasyonu yöneticilerinin ve oyuncuların belirttiği üzere, burada 50 yıldan daha uzun süreden beri kullanılmakta olan oyun masalarının bulunmasıdır. 

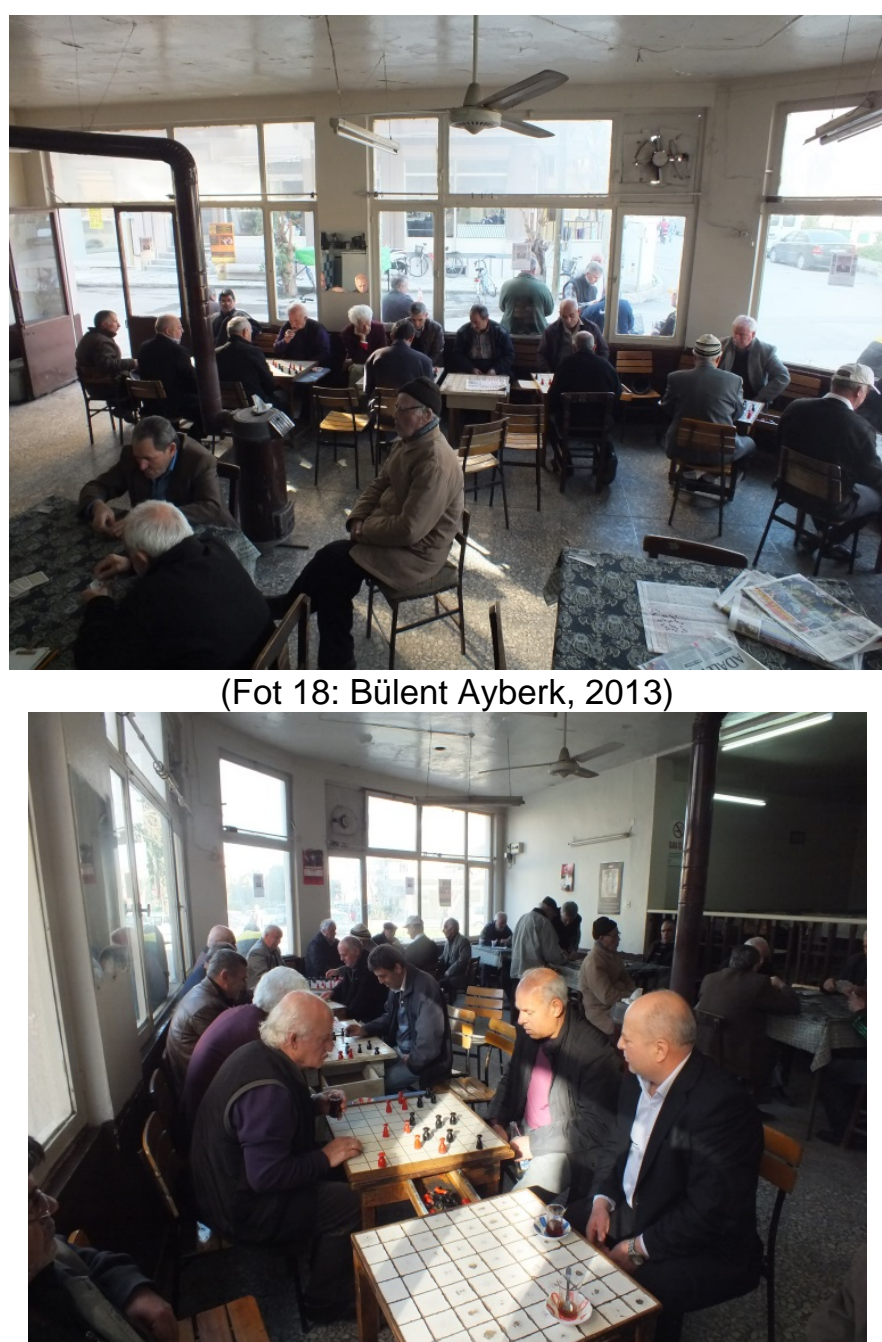

(Fot 19: Bülent Ayberk, 2013)

\subsection{Manisa}

Manisa'da dama oynanan kahvehane, Eski Çarşı içerisinde 1808 sokaktadır. Üç katı bir apartmanın zemin katında bulunan kahvehane, kare bir plana sahiptir. Burada, dama dışında diğer masa oyunları da oynanmaktadır. Özellikle duvar dibinde oluşturulan sabit doğrusal oturma elemanı, kahvehanenin müdavimi olan dama oyuncularının varlığını ve dama oyun kültürünün yerleşikliğini göstermektedir (Fot.20). Dama oyun birimi içerisinde bulunan ve çeşitli gereksinimleri karşılayan ara birim olan sehpa burada kullanılmamıştır. Bu birim, sabit olan oturma mobilyasına, masaların arasından ulaşımı kolaylaştırmak amacıyla kaldırılmıştır. Oyuncular, dama masasının oyun sırasında taş dizilmeyerek boş bırakılan 8. sırasını çay bardağını ya da kahve fincanın koymak için kullanabilmekte ya da oyun süresince ellerinde tutmaktadırlar (Fot.21). 


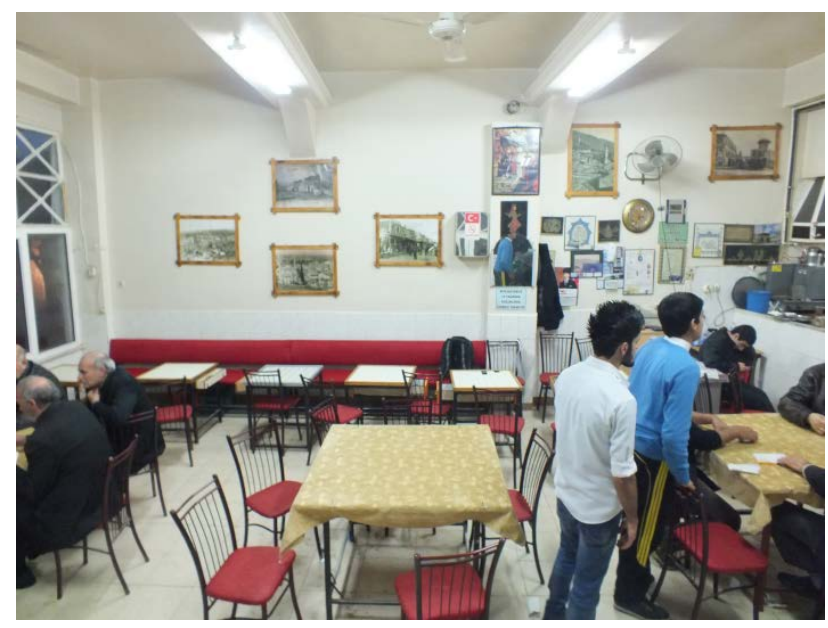

(Fot.20: Bülent Ayberk, 2013)

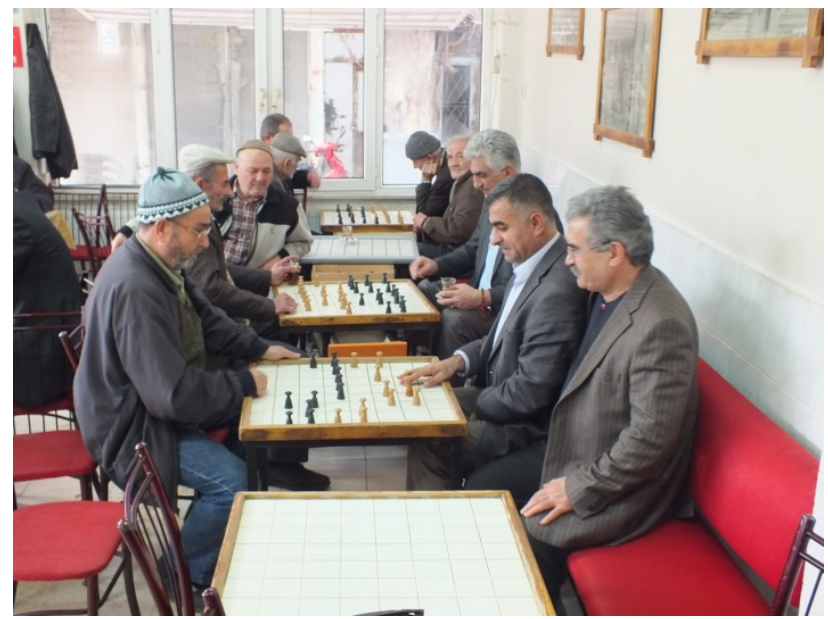

\subsection{Menemen}

(Fot 21: Bülent Ayberk, 2013)

İzmir Menemen'de Kılıçarslan Sokak'ta yer alan kahvehane metal konstrüksiyon ve branda gibi hafif malzemeler kullanılarak kurulan geçici bir mekân görünümündedir. Mekân içinde noktasal olarak konumlandırılan diğer oyun masaları arasında doğrusal bir konumlandırma ile dikkat çeken dama masaları, yerleşim hiyerarşisi içinde ikincil bir durumda bulunmakla beraber, oyunun gereksinimleri nedeniyle mekânın plan olarak örgütlemesine bir örnek oluşturmaktadır (Fot.22). 


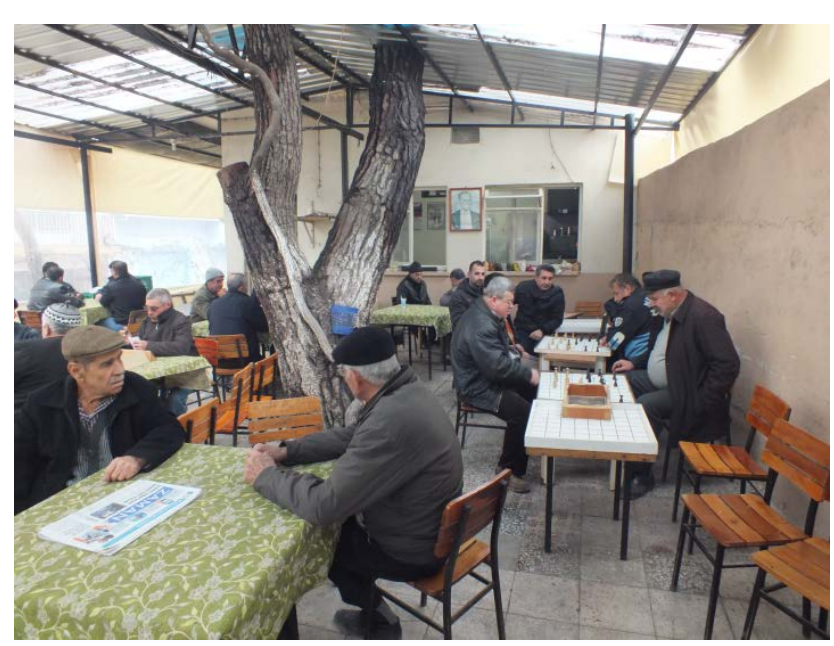

\subsection{Mustafakemalpaşa}

(Fot.22: Bülent Ayberk, 2013)

Mustafa Kemal Paşa, "Damanın Kırkpınarı" sloganı ile Türkiye'nin en köklü dama turnuvasına ev sahipliği yapmaktadır. Burada bulunan Asmalı Kahvehane olarak adlandırılan dama kahvehanesi, kentin bu özelliğine koşut bir biçimde kültürel olarak önemli bir konum yüklenmektedir. Burada diğer kahvehanelere benzer biçimde doğrusal bir yerleşim görülmektedir (Fot.23). Ancak dama masalarının biçimi ve ayrıntıları dikkat çekicidir. Burada karşılaşılan dama masası ve çevresel elemanlarının bir bütünde toplanarak, üreticinin yorumu ile ne kadar farklılaşabildiği ve başarılı ürünler ortaya çıkabileceğinin çapıcı bir örneğidir.

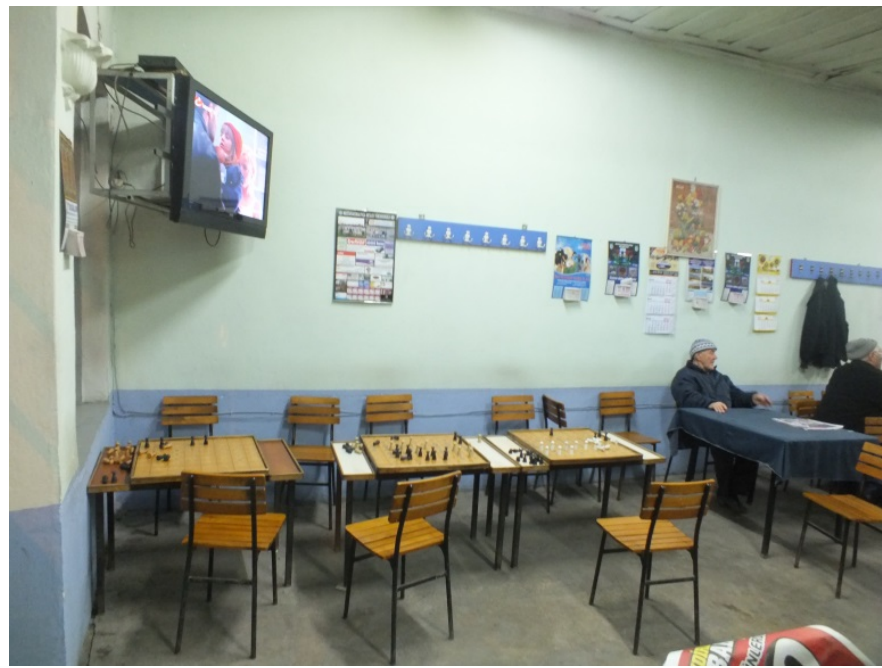

(Fot.23: Bülent Ayberk, 2013)

\subsection{Nazilli}

Nazilli Damacılar ve Damasevenler Derneği, 2010 yılında kurulmuştur. Daha önce bölgesel turnuvalar düzenleyen dernek, 2011 yılından bu yana uluslararası dama şampiyonası düzenlemektedir ${ }^{8}$.

\footnotetext{
${ }^{8}$ Buradaki bilgi, Nazilli Damacılar Derneği Başkanlığını yürüten Hüsamettin Özer'den 2013 yılında Nazilli'de yapılan görüşme ile sağlanmıştır.
} 
Damacılar Derneği, dama oyuncuları ve üyeleri için Karaçay Mahallesi, 1007 Sokak'ta bulunan kahvehanenin mekânından yararlanmaktadır. Açık ve kapalı olarak ikiye ayrılan kahvehanede açık olan bölümün özellikle soğuk mevsimlerde branda ve saydam örtücülerle kapatılması ile oluşturulan mekânı dama oyuncuları kullanmaktadır (Fot.24) Sıcak mevsimlerde toplanan branda ile açık alana dönüşen bu bölüm, sokakla yoğun iliş̧kisi olan bir mekâna dönüşmektedir.

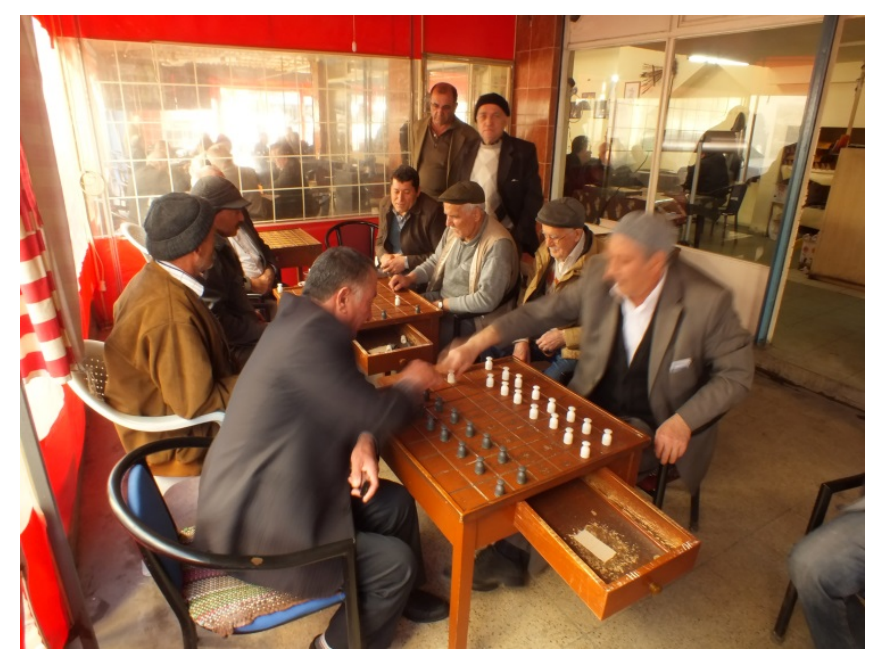

(Fot.24: Bülent Ayberk, 2013)

\subsection{3. Şanlıurfa}

Gümrük Han, 1563 yılında Urfa Sancak Beyi Halhallı Behram Paşa tarafından yaptırılmıştır (URL-3). Yaz mevsiminde handa bulunan geniş avlu, kahvehane oyuncuları tarafından kullanılmaktadır. Burada kahvehane olarak işlev gören mekân içinde farklı türde masa oyunları oynanmaktadır. Dama oyuncularının oturma birimi olarak özellikle kürsüyü tercih etmesi, ayrılan bu bölümü farklılaştırmaktadır (Fot.25). Burada da benzer biçimde sehpalar üzerine koyularak oyun birimlerine dönüştürülen oyun masaları bulunmaktadır (Fot.26).

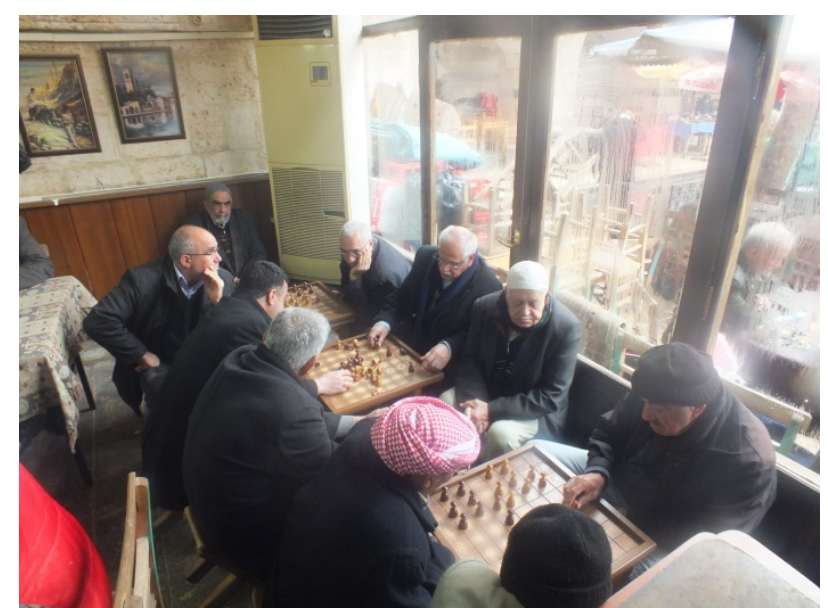

(Fot.25: Bülent Ayberk, 2014) 


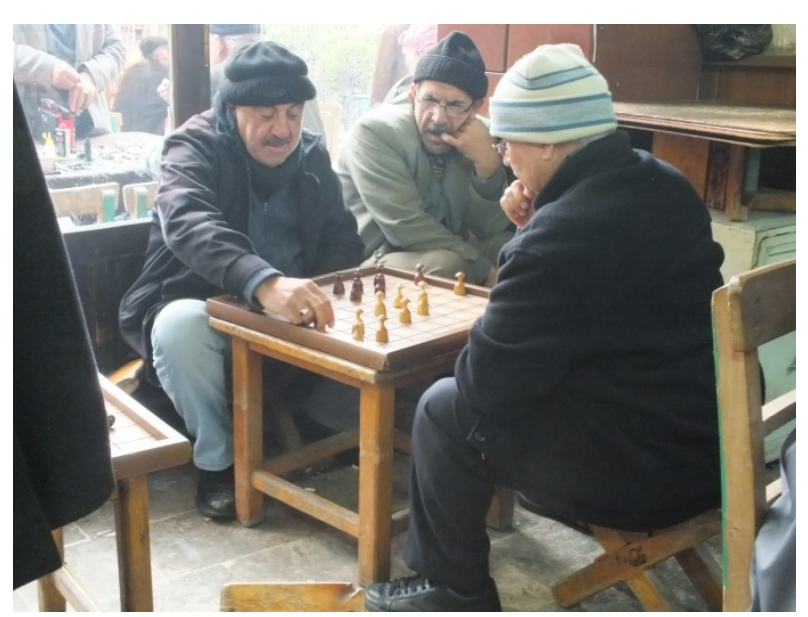

(Fot.26: Bülent Ayberk, 2014)

\subsection{Tire}

Türkiye'de dama oynanan ancak "damacılar kahvesi" adını taşıyan sayısı çok kahvehanelerden biri İzmir'in bir ilçesi olan Tire'de bulunmaktadır (Fot.27). Çok az sayıda dama masasının bulunduğu kahvehane, bu özelliğini diğer masa oyunlarının mekânda yer almasıyla yitirmiş görünmektedir (Fot.28). Görsellerin çekildiği 2014 yılında iç mekânda bilardo masası bulunmaktaydı.

Tire'deki diğer kahvehanelerde de dama masaları bulunmakta; oyun oynamak isteyenler bu masalardan yararlanabilmektedir.

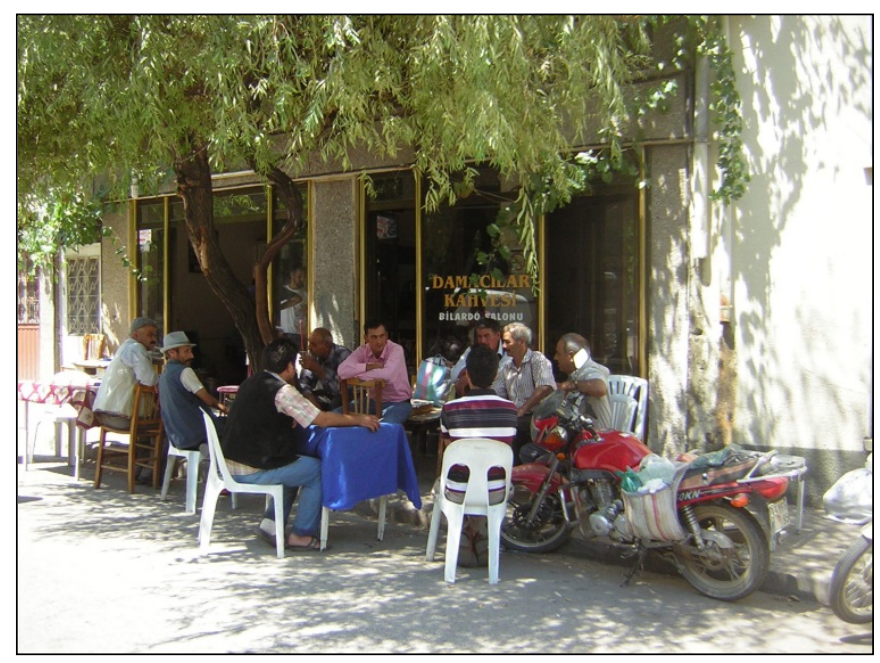

(Fot.27: Bülent Ayberk, 2014) 


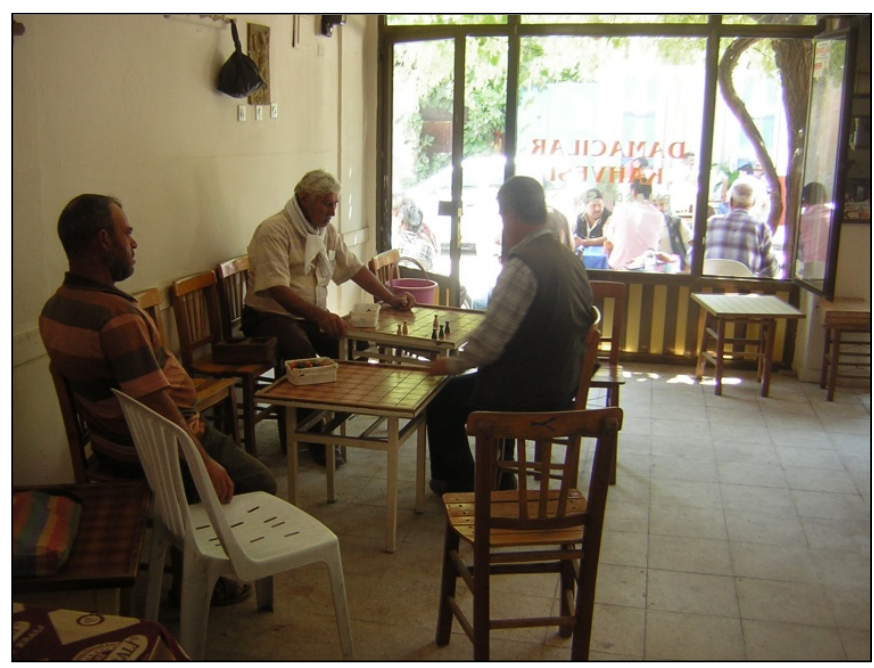

(Fot.28: Bülent Ayberk, 2014)

\subsection{Turgutlu}

Manisa'ya bağlı Turgutlu'da dama oyunu oynanması için özelleşmiş bir dama kahvesi bulunmaktadır. Açık ve kapalı olmak üzere iki bölümden oluşan kahvehane, L biçiminde bir plana sahiptir. Burada dama masaları mekânın geneline doğrusal bir planlama ile konumlandırılmış olmakla beraber (Fot.29) mekân, işlevsel olarak verimsiz kullanılmaktadır.

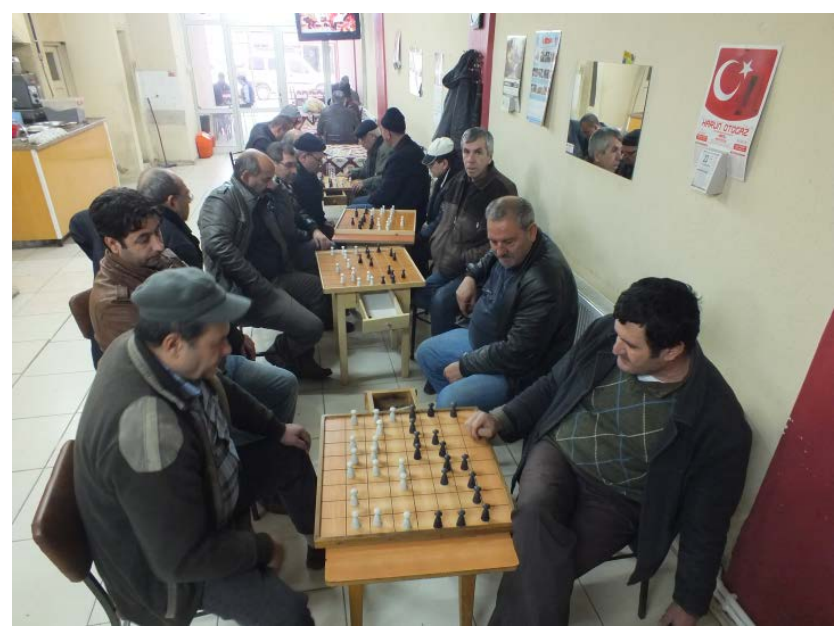

(Fot.29: Bülent Ayberk, 2013)

\section{DEĞERLENDIRME}

Tanzimat Fermanı sonrasında ortaya çıkan toplumsal değişim rüzgarı, Osmanlı İstanbul'unda yaşamı etki altına almış, dolayısıyla günlük kullanım eşyalarında da değişime neden olmuştur. Özellikle oturma biçimi geleneğimizde bulunan peyke, sedir ya da tabure-kürsü gibi mobilyalar yerini sandalye ve masa kullanımına bırakmıştır (Kut, 1981). Oturma kültüründeki bu değişim, Osmanlı dönemi gezginlerinin kahvehane betimlerindeki oturma biçimlerini, özellikle Türkiye'nin batısında giderek ortadan kaldırmıştır. Bununla birlikte, doğuda da belirli bir dönüşüme uğramakla beraber farklı otuma biçimlerinin kahvehanelerin iç mekânlarında hala sürdürüldüğü görülmektedir. Bu noktada yöresel söyleyişle, kürsü olarak adlandırılan mobilya, buna bir örnek olarak gösterilebilir. Bursa'da bulunan kahvehanede görüldüğü üzere bir 
oturma mobilyası olan ranzanın karşılamış olduğu oturma biçimi gereksinimi, farklı kahvehanelerde farklı mobilyalarla karşılanmaya çalışılmıştır (Fot 10).

Bursa'daki kahvehanedeki oyun masası ise oturma yüksekliğinin geçirdiği dönüşüm ile standart bir oyun masasının yüksekliğine ulaşmıştır ki, bu durum çok önemlidir. Her ne kadar, çoğunluğunu yaşı ileri olan kullanıcı kitlesinin fiziksel sorunlarına çözüm amacı ile böyle bir biçim ortaya çıkmış olsa bile; dama oyun mobilyasının bu biçimi, oyun kültürüne, iç mekânına ve mobilyasına önemli bir katkı yapmaktadır.

Burada şunu da belirtmek gerekmektedir. Dama masası ve çevresel birimleri, üreticinin yorumu ile farklı biçimler olarak karşımıza çıkabilmektedir ki; bu durum, kahvehanelerin iç mekânında çeşitlilik ve varsıllık yaratmaktadır. Bu farklılaşma, mobilyaların ayrıntılarının üretimindeki seçimlerle de ortaya çıkabilmektedir.

Oyun masasının yüksekliği yöresel oturma alışkanlıklarına bağı olarak düşebilmektedir. Ancak, yükseklik, oyuncunun kolaylıkla algılayabileceği ve oyun yüzeyine görsel olarak egemen bir açıda bakabileceği bir yükseklik içerisinde kalmak zorundadır. Oyun sürecinde görsel algılama, oyuncular tarafından çok önemsenmektedir. Bu nedenle, bazı dama oyuncuları, özellikle beyaz taşın dama oynanan yüzey üzerindeki algılanmasının yaratabileceği sorunu ortadan kaldırmak için sarı ya da kırmızı gibi farklı renkleri kullanmaktadırlar.

Oyun masasının ve oturma mobilyasının yüksekliği, oturan oyuncunun dizlerinin açıklığını, bu da doğrudan doğruya oyun yüzeyinin genişliğini etkilemektedir. Bu oyun birimi tipolojisine alışan kullanıcılar, turnuva amacıyla gittikleri kentlerde sandalye ve masa ile oluşan bir oyun biriminde çok zorlandıklarını belirtmektedirler.

Oyun masalarının konumlandırılmasında kullanılan doğrusal yerleşim; dama masası, oturma elemanı (sandalye, tabure) ve yan sehpadan oluşan birimin yinelenmesiyle oluşmaktadır. Bununla birlikte yine yöresel özelliklerin getirdiği etkiler sonucunda noktasal birimlerle de mekân örgütlenmesi biçimlenebilmektedir. Tüm bu mekân kurgusunda farklı yörelerdeki damacıların oyun anlayışları ve iletişim özellikleri rol oynamaktadır. Özellikle doğu illerimizde yoğun bir iletişim ortamının olduğu dama oyununda, oyun oynayan iki kişiden görece daha iyi bir oyuncu olan rakibine karşı, diğer damacıya taktik vermek amacıyla izleyiciler oyuncuya yardımcı olmaktadırlar. $\mathrm{Bu}$ davranış biçimi dama masasının etrafında dairesel toplanmalara neden olmaktadır.

Dama oyunu, bu coğrafyadaki derin geçmişine karşın toplumumuz tarafından yeterince tanınmamaktadır. Özellikle Türk kültüründe her zaman var olmuş olan dama, zaman içerisinde çeşitli nedenlerden dolayı önemini kaybetmiştir. Bu durumda, kuşkusuz Batılılaşma atılımlarının yanlış yorumlanmasının ve geleneksel ayırt edici özelliklerimizin yitirilmesine neden olan tutumların da payı olduğu gözlemlenebilmektedir. Cumhuriyet dönemiyle birlikte artan okuma yazma oranı sonucu dama topluluğu içinde yer almaya başlayan eğitimli insanlar sayesinde dama oyunu daha bilinçli bir oyuncu kitlesine kavuşmuştur.

Federasyonların altında kurumsallaşan dama topluluğu Türkiye'nin farklı yerlerinde dama için etkinlikler düzenleyerek bu geleneksel oyunun ülkemizde sevilmesine, daha doğru bir tanımlama ile toplum tarafından yeniden anımsanmasına çaba göstermektedir. Öte yandan, Türkiye'de gerek mekân kurgusu gerekse mekân içinde yer alan dama masalarının tarihsel değeri ve işçiliği nedeni ile göz ardı edilemeyecek önemde kültürel öğeler bulunmaktadır. Damaya ilişkin kültürel mirasın toplanması derlenmesi ve ileriye götürülmesi için dama federasyonları tarafından geliştirilen stratejiler arasında dama federasyonlarının üniversiteler ile yapacakları ortak 
çalışmalar ile mobilyaların ve mekânların kayıt altına alınması ve envanterinin çıkarılması da gelecek planları arasında yer almaya başlamalıdır.

\section{KAYNAKÇA}

"Dama”, Ana Britannica Genel kültür Ansiklopedisi, Cilt 7, İstanbul, 1987,s.n.y.

Çiftçi, Hasan, Güldeste, Bektaş, Osmanlı Döneminden Günümüze Kadar Ulaşan Türk Daması Açmaz Oyunları ,Türk Daması Federasyonu , 2015

Akgündüz, Ahmed, "Bir Aile Ve Hizmet Müesesesi Olarak Osmanlı'da Harem”, H.C. Güzel, K.Çiçek, S. Koca (Ed), Türkler. Yeni Türkiye Yayınları, Ankara, 2012

Baykur, R. İnanç, Damaya Güzelleme, YGS Yayınları, İstanbul, 2008

Birsel, Salah, Kahveler Kitabı, Sel Yayıncılık, İstanbul, 2009

Büyük Larousse - Sözlük ve Ansiklopedi: cilt 6, s.n.y.

Celal, Musahipzade, Eski İstanbul Yaşayışı, Türkiye Yayınevi, İstanbul, 1946

Cengiz, Murat, Masa Oyunlarında Görsel-İçerik Illişkisi ve Uygulama Çalışması, Yayımlanmamış Yüksek Lisans Tezi, Dokuz Eylül Üniversitesi, 2008

Çobanoğlu, Özkul, "Osmanlı Devleti'nde Türk Halk Kültürü'nün Değişim ve Dönüşüm Dinamikleri", Türkler, (Ed: H.C. Güzel, K.Çiçek, S. Koca), Yeni Türkiye Yayınları, Ankara, 1999

Çağlayan, Savaş, “Anadolu'nun Illk Kamusal Mekanı: Kahvehaneler”, Muğla Sıtkı Koçman Üniversitesi Sosyal Bilimler Enstitüsü Dergisi, Muğla, 2012, 29

Erdoğru, Mehmet Akif, "Osmanlı Kıbrısı'nda Kahve Ve Kahvehaneler (1594-1640) ", Türkler, (Ed: H.C. Güzel, K.Çiçek, S. Koca), Yeni Türkiye Yayınları, Ankara, 2002

Emeksiz, Abdülkadir, "İstanbul Kahvehaneleri” Karaların Ve Denizlerin Sultanı İstanbul, (Ed: Özden, Filiz), Cilt 2. Yapı Kredi Yayınları, İstanbul, 2009

Felek, Burhan, “Perşembenin Gelişi”. Cumhuriyet Gazetesi, 1959, 26 Haziran

Georgeon F., Georgeon F, Gregoire H. D. (Ed), Doğuda Kahve Ve Kahvehaneler: Osmanlı Imparatorluğu'nun Son Döneminde İstanbul Kahvehaneleri, Yapı Kredi Yayınları, İstanbul, 1999

Gül, İsmail, Osmanlı Devletinde Sultan IV. Murad Dönemi Yeniçeri İsyanları (1623 1640), Yayımlanmamış Yüksek Lisans Tezi, Sakarya, 2006

Güldeste, Bektaş, Türk Daması İlk Öğretim Ders Kitabı, Türk Daması Federasyonu, 2015

Kut, A, Kahvehaneler, Yurt Ansiklopedisi, İstanbul, 1981,s.n.y

Kömeçoğlu, Uğur, Homo Ludens ve Homo Sapiens arasında Kamusallık Ve Toplumsallık: Osmanlı Kahvehaneleri, Yaşar, A. (Ed), Kitap Yayınevi, İstanbul, 2010 
Ulunay, Refi' Cevat, “Yine Damacılar”, Milliyet Gazetesi, 1964, 02 Ağustos

Ulunay, Refi' Cevat, “Damacı Edhem Efendi, Milliyet Gazetesi, 1967, 26 Haziran

Ünver A. Süheyl, Türkiye'de Kahve ve Kahvehaneler, Türk Tarih Kurumu Basımevi, Ankara, 1963

Örnek, Ali Erdoğan, Dama, Oyunlar ve Açmazlar, Yazarın Kendi Yayını, İstanbul, 1974

Selvi, Bener Salkım, "Eski Yunan Ve Roma'da Oyun Ve Oyuncaklar", Yüksek Lisans Tezi, İstanbul Üniversitesi, 2008

Sökmen Cem, Aydınların İletişim Ortamı Olarak Eski İstanbul Kahvehaneleri, Ötüken Neşriyat, İstanbul, 2011

Yaşar, Ahmet, "Geçmişini Arayan Osmanlı Kahvehanesi", (Ed: Yaşar A.), Osmanlı Kahvehaneleri: Mekan, Sosyalleşme, Iktidar, Kitap Yayınevi, İstanbul, 2010

URL 1: "Batmanlı damacılar turnuvaya katılıyor", Batman Gazetesi, 2012, 30 Ağustos, 2015, 24.00

URL 2: “Dama tutkunları", Batman Gazetesi, 2013, 28 Temmuz, 2015, 24.00

URL 3: sanliurfa.gov.tr, 2013, 2015, 22.00. 